\title{
Teaching for conceptual understanding: A cross-national comparison of the relationship between teachers' instructional practices and student achievement in mathematics
}

Laura M O'Dwyer ${ }^{1 *}$, Yang Wang ${ }^{2}$ and Katherine A Shields ${ }^{3}$

\author{
* Correspondence: \\ laura.odwyer@bc.edu \\ 'Department of Educational \\ Research, Measurement and \\ Evaluation, Lynch School of \\ Education, Boston College, Chestnut \\ Hill, Massachusetts, USA \\ Full list of author information is \\ available at the end of the article
}

\begin{abstract}
Background: Educators, researchers and policy-makers worldwide continue to struggle to understand the changes needed for improving educational outcomes and attainment for students, particularly in content areas such as mathematics and science that are essential for developing a highly skilled workforce. Given the continuing emphasis on linking teacher practices with student outcomes, this study aims to explore teachers' use of particular instructional strategies and whether use is associated with student achievement.

Methods: Using data from the Trends in International Mathematics and Science Study (TIMSS) 2007, this study examines eighth grade teachers' use of instructional practices that support students' conceptual understanding, and examines the relationship between those practices and mathematics test scores. Data from four countries was examined: U.S., Korea, Japan, and Singapore. Descriptive statistics and a series of multilevel regression models were used.

Results: The results show that teachers in the U.S. were most similar to Korean teachers in the frequency and types of teaching practices reported, and that they reported using some practices at least as frequently, or more frequently than teachers in the other countries. A sub-set of teachers' instructional practices are related to mathematics achievement in the U.S. and Singapore, but not in Korea or Japan.

Conclusions: Teacher practices explained very little of the variability in test scores, even in cases where particular instructional practices were positively and significantly related to achievement. This research highlights the challenges for examining the teacher-level correlates of student test scores using data from cross-sectional, international studies that do not include measures of students' prior achievement, classroom observations, or estimates of students' out-of-school instruction.

Keywords: Mathematics achievement; Teachers and teaching; Instructional practices; TIMSS
\end{abstract}

\section{Springer}

() 2015 ODwyer et al.; licensee Springer. This is an Open Access article distributed under the terms of the Creative Commons Attribution License (http://creativecommons.org/licenses/by/2.0), which permits unrestricted use, distribution, and reproduction in any medium, provided the original work is properly credited. 


\section{Background}

Researchers and policymakers worldwide have an ongoing interest in understanding the ways in which teachers contribute to students' learning and academic achievement. In the U.S. for example, prompted by the most recent federal investments in education, the Race to the Top program authorized under sections 14005 and 14006 of the American Recovery and Reinvestment Act of 2009 (ARRA), which places specific emphasis on improving teacher quality, researchers, policy-makers and practitioners are increasingly interested in the interplay between teacher quality and student achievement. However, as with many constructs in education, teacher quality is a multidimensional construct that includes not only teacher qualifications, but also teachers' pedagogical content knowledge, their professional development activities, their instructional practices and quality, as well as their attitudes toward students and teaching (DarlingHammond and Youngs, 2002; Goe, 2007). While several studies have linked overall measures of the quality of instructional practice (such as standardized teacher evaluation ratings) to student test scores (Borman and Kimball, 2005; Heneman et al., 2006; Holtzapple, 2003; Kimball et al., 2004; Milanowski, 2004), other studies have found no such connections (e.g., Gallagher, 2004; Rowan et al., 1997; D'Agostino, 2000). Overall, there appears to be little consensus on the specific instructional strategies that are consistently associated with student achievement.

The purpose of this research is to describe patterns in teachers' instructional practices in eighth-grade mathematics classrooms in four countries that participated in the Trends in International Mathematics and Science Study (TIMSS) 2007 (the U.S., Korea, Japan, and Singapore), and to examine the relationship between teachers' instructional practices and students' achievement in mathematics. This research also highlights the challenges for using data from international cross-sectional comparative studies to link student outcomes with teachers' instructional practices.

\section{Instructional practices and student achievement}

Demonstrating relationships between specific teaching practices and student achievement has proven difficult. From a methodological perspective, cross-sectional educational research designs do not allow us to know whether a teacher is using a particular strategy because that teacher has high-achieving students, or whether that strategy is producing high-achieving students. Likewise, cross-sectional studies that lack information about students' prior achievement make it difficult to disentangle a single teacher's contribution to students' achievement.

Beyond these challenges, Hiebert and Grouws (2007) attribute the lack of consensus on the relationship between instructional strategies and student achievement to an absence of well-developed theories describing how teaching practices affect learning; to the varying effectiveness of a given teaching approach that depends on the learning goals; and to the mediating effects of student and contextual variables. However, evidence has accumulated for the effectiveness of some teaching practices. For example, Hill et al. (2005) found that teachers' pedagogical content knowledge, the specialized mathematical knowledge and skills used in teaching mathematics, were positively associated with gains in students' mathematical achievement over time.

Likewise, Hattie's (2009) exhaustive synthesis of meta-analyses of research on student achievement identifies a number of teaching strategies with moderate-to-large effect 
sizes across multiple studies. These strategies include "problem-solving teaching," which is defined as a set of methods that help students to define the problem, then assess and select among possible solutions. In alignment with Hattie's findings, Camburn and Han (2011) found support for a significant effect for problem-solving and related instructional strategies in a review of evidence from the past twenty years of student achievement studies based on large-scale assessments. The associated student activities included "solving novel problems, engaging in reasoning and analysis, and making connections to real world applications of knowledge" (p. 593). These practices can be understood within the framework of conceptual and procedural mathematics knowledge (Hiebert and Lefevre, 1987; Hiebert, 2003).

Conceptual knowledge is the understanding of core principles and the relationships among them (Hiebert and Lefevre, 1987; diSessa and Sherin, 1998; Star, 2005). Hiebert and Grouws (2007) outline two key aspects of instructional practices that help students develop conceptual understanding: giving students the opportunity to "struggle" with problems (p. 387), and discussing conceptual relationships "explicitly" (p. 383). These approaches help students develop the ability to transfer their skills and knowledge to new contexts. Prawat (1989a), whose work was a resource for the TIMSS conceptual framework underlying the teacher and classroom context surveys, connects conceptual knowledge development with teacher practices that attend to students' explanations and problem-solving strategies. By contrast, procedural knowledge is limited to recognizing the mathematical system of symbols and rules, and carrying out procedures using that system (Star, 2005). Conceptual knowledge allows the student to select and apply the right procedure for the situation, and to incorporate new information correctly into what he or she already knows (Prawat, 1989b). In the U.S., the National Council of Teachers of Mathematics (NCTM) (2000) recognizes the importance of conceptual understanding, calling for students to learn "with understanding, actively building new knowledge from experience and previous knowledge" and "reflecting on their thinking" (p. 2).

Teaching practices that help students to develop conceptual knowledge have been linked to achievement in the literature. These practices include: giving students challenging assignments (Newmann et al., 2001; Schacter and Thum, 2004); providing opportunities to apply learning and solve unique problems (Wenglinsky, 2002); spending time on conceptual activities such as estimation, writing equations, and word problems (Lubienski, 2006); and having students discuss the reasons behind their answers to questions (Gales and Yan, 2001). The research companion to the NCTM Standards (Mewborn, 2003) also cites studies that link higher achievement to providing students with opportunities to solve problems and talk with each other about their approaches (Fennema, et al., 1996), as well as helping students see the associations between concepts and mathematical symbols (Gearhart et al., 1999).

\section{Evidence from international comparative studies}

With the almost 20 years of available data from international comparative studies in education such as the TIMSS, the Progress in International Reading Literacy Study (PIRLS), and the Programme for International Student Assessment (PISA), secondary analyses have been conducted in individual counties that examined the relationship between teachers' instructional practices and student achievement. For example, using TIMSS 1995 eighth grade data in the U.S., Tomoff et al. (2000) compared 
the NCTM-recommended practices to those reported by the sample of TIMSS mathematics teachers and found that the use of drill and review exercises was significantly negatively associated with mathematics achievement. Their study also showed that more interactive, conceptual activities such as group and project-based work showed no relationship. In Japan, House (2009) found that higher-achieving fourth grade students in the 2007 TIMSS sample reported being asked more frequently to work on problems independently and to explain their answers, although procedural skills such as memorization of procedures and practicing computation were also positively related to achievement in this younger population.

A small number of researchers have used data from international comparative studies to describe the differences in teachers' instructional practices across countries, and to examine the relationship between instructional practices and achievement. For example, as part of a multi-country study using 1999 TIMSS eighth grade data, Desimone et al. (2005) analyzed whether teachers' use of conceptual versus computational instructional strategies was predictive of classroom-level mathematics achievement. The authors found weak relationships within countries, and no meaningful variation in the strength of this relationship across countries. In country-specific analyses, they found a weak positive association between conceptual instruction and achievement in the U.S., but no such relationship in Singapore or Japan.

\section{Evidence on instructional practice in the U.S. and East Asia}

In the U.S., researchers, policy-makers, practitioners, and even the general public are keenly aware that multiple international studies have shown that our students consistently lag behind students in some countries, particularly students in East Asian countries. For example, on the 2007 TIMSS and PISA assessments, U.S. middle school students performed below the OECD mean in mathematics, and lagged behind the East Asian countries; Singapore, Korea and Japan ranked among the top five countries in TIMSS and the top 10 in PISA, compared to the U.S. at $9^{\text {th }}$ in TIMSS and $31^{\text {st }}$ in PISA (Mullis et al., 2008; OECD, 2010). Moreover, evidence shows that only 6\% of U.S. students scored in the advanced category of TIMSS, compared to $40 \%$ of students in Korea and Singapore, and 26\% in Japan (Mullis et al., 2008).

Studies that have explored explanations for what distinguishes East Asian nations from lower performing countries, including the U.S., reported various differences including stronger teacher preparation (Heck, 2007; Kim et al., 2011) and a uniform, coherent national curriculum (Schmidt et al., 2005). Some strands of research also explore the cultural roots of these differences, such as a predominant focus on the collective, a greater emphasis on hard work and practice, and the role of the teacher as content expert in the Eastern tradition, compared to a focus on the individual and child-centered pedagogy in the Western tradition (Kaiser and Blömeke, 2013). Other researchers point to the amount of time spent both in and outside of school on mathematics instruction as an important distinguishing characteristic (Lewis and Seidman, 1994, Bray, 2003; Bray and Kwo, 2013). In particular, valid comparisons across education systems may be hampered by the existence of for-profit, supplementary "shadow education" systems that operate in parallel to those sampled in international comparative studies. Despite their strong education systems, cram schools, referred to as juku in Japan and hagwons in Korea, are ubiquitous in many East Asian countries 
(Bray and Kwo, 2013). In Singapore for example, the number of juku almost tripled between 1994 and 2002 (Bray, 2003) and in 2008 in Korea, more than $70 \%$ of middle school students received extensive tutoring outside of the country's formal education system sampled and assessed by international comparative studies (Bray and Kwo, 2013).

Related to instructional practice differences, classroom observational studies suggest that teachers in higher-performing countries tend to use strategies that support conceptual knowledge development more frequently than their peers in the U.S., where teachers spend more time nurturing basic procedural skills at the expense of critical thinking and understanding of underlying concepts (Prawat, 1989a). This finding is supported by the 1999 TIMSS video study, which collected classroom observations from randomly selected classrooms in six high-performing countries and the U.S., and reported that teachers in U.S. classrooms spent more time completing repetitive exercises rather than applying and extending skills to new, different problems; reviewed previously taught procedures and material more frequently; covered less advanced content; covered a scattered mix of skills and concepts rather than a single coherent topic; and suffered more interruptions to the lesson (Hiebert et al., 2005). Researchers have also found that teachers in Japan (Whitman and Lai, 1990) and Singapore (VanTassel-Baska et al., 2008) focused more on critical thinking and lesson structure, when compared to U.S. teachers who focused more on discipline and rules. Japanese teachers also reported a more unified view of what constitutes "good" mathematics instruction than their American counterparts (Jacobs and Morita, 2002).

\section{Research purpose}

Recognizing the limitations of international cross-sectional studies of educational outcomes that use self-report instructional practices, the present study seeks to extend the field's understanding of the relationship between teaching for conceptual understanding and mathematics achievement using TIMSS 2007 data. The objective of this research is to describe patterns in teaching for conceptual understanding in eighth-grade mathematics classrooms in the U.S. and three East Asian countries, Korea, Japan, and Singapore, and to examine how teaching for conceptual understanding in mathematics classrooms is associated with students' achievement in mathematics. Korea, Japan, and Singapore were selected as comparisons to the U.S. because, over repeated international studies, they have out-performed the U.S. For example, while the mean mathematics scores for the U.S., Korea, Japan, and Singapore were each above the TIMSS international mean (i.e., 500) across the 49 participating countries/jurisdictions in 2007, the means in 2007 for Singapore (593), Japan (570), and South Korea (597) were each higher than the mean in the U.S. (508). Moreover, this pattern of lower mean achievement for the U.S. compared to these countries was observed in all past TIMSS administrations for mathematics - TIMSS 1995, 1999, 2003, and most recently in 2011.

Using TIMSS 2007 data from individual students, data from their mathematics teachers, as well as information about their schools, this research addresses the following research questions:

1. How does teaching for conceptual understanding in mathematics classrooms vary across the U.S., Korea, Japan, and Singapore? 
2. Within these four countries, is teaching for conceptual understanding associated with students' mathematics achievement? And, do the associations between teaching for conceptual understanding and students' mathematics achievement vary across the U.S., Korea, Japan, and Singapore?

These questions were addressed using teacher data and individual student data, and analyses were conducted separately by country. Descriptive analyses and ANOVA with teacher data were used to address the first research question, and a series of two-level hierarchical linear regression models with student, teacher and school data was used to address the second research question. In addition to addressing these research questions, this study highlights the challenges for using data from cross-sectional, international comparative studies to link student outcomes with teachers' instructional practices.

\section{Methods}

This section describes the TIMSS 2007 sample, the variables and measures derived from the TIMSS student, teacher, and school questionnaire data, and the data analyses used to address the research questions. Explicit descriptions of the model specifications used to estimate the relationship between teachers' instructional practices and student achievement are also provided ${ }^{\mathrm{a}}$.

\section{TIMSS 2007 sample}

The final analysis sample for each country was defined after the data files were cleaned according to specific criteria. First, students with missing cases on the student-level covariates were removed from the analysis sample ( $2 \%$ or 164 students in the U.S., $0.03 \%$ or 14 students in Korea, $1 \%$ or 35 students in Japan, and $0.5 \%$ or 21 students in Singapore). Studies have shown that estimates are not sensitive to the choice of treatment of missing data at such minimal levels (Little \& Rubin, 2002), and so we do not expect the listwise deletion of these small numbers of cases to introduce bias.

Second, students and classrooms linked with more than one mathematics teacher were removed from the analysis sample. This step ensured that only students whose test scores could be linked with one teacher were included in the analyses, a necessary condition for examining the association between teachers' instructional practices and student achievement. Through this process, 216 students were removed in U.S. (3\%) and 58 students in Korea (1\%). In Japan, the number of students removed at this step was large, $1212(22 \%)$, and because in many schools all students were linked with more than one teacher, 37 schools (of the available 146) were removed from the sample at this stage. In Singapore, 171 students (4\%) in two schools (of the available 164) were removed.

Third, some classrooms were randomly removed from the analysis sample to allow comparisons across countries. The TIMSS sample is selected using a two-stage stratified sampling procedure to produce a representative sample of students from participating countries; schools are randomly sampled at the first stage and intact classrooms are sampled within each sampled school at the second stage (Joncas, 2008). The majority of TIMSS countries randomly sampled only one intact classroom in each school, resulting in classroom effects being confounded with school effects. However, some countries (e.g., the U.S. and Singapore) routinely sampled more than one classroom per school. To allow direct comparisons among the four countries included in this study, 
one classroom was randomly selected within each school to be included in the analyses. This process resulted in the random removal of 192 classrooms in the U.S., 20 in Japan, and 133 in Singapore. No classrooms were removed from the Korean sample since all schools sampled only one classroom. As a consequence of including only students from one mathematics classroom and their mathematics teacher, the classroom and school levels are confounded. In describing the analyses and the results we refer to the between school effects, recognizing that they could also be considered between classroom effects.

Finally, schools fewer than five students were removed from the analysis sample (only one in Japan and none in the other three countries) and schools with missing teacher instructional practice data were removed from the analysis samples (23 schools in the U.S., no schools in Korea, one school in Japan, and two schools in Singapore).

Overall, the analyses were conducted with data from 217 schools and 3255 students in the U.S., 150 schools and 4102 students in Korea, 107 schools and 2719 students in Japan, and 160 schools and 2270 students in Singapore. Table 1 shows that mean achievement and the variability in achievement were similar in the reported samples (Mullis et al. 2008) and the analysis samples. Moreover, the percentages of students whose teachers asked them to engage in the six activities in about half the lessons or more were similar in the reported and analysis samples.

\section{Variables and measures}

The research questions were addressed using students' eighth grade mathematics achievement, the instructional practices reported by their teachers, as well as information about the student body in the sampled schools. The teacher instructional practice measures were derived from teachers' responses to the mathematics teacher survey. In addition, the analyses included student and school covariates derived from the student and school questionnaires. The student achievement and teacher practice measures, as well as the student and school covariates are discussed in turn.

\section{Mathematics achievement}

At the eighth grade, the student mathematics assessment comprised four sub-domains, each contributing to a total mathematics score: Number (30\%), Algebra (30\%), Geometry (20\%), and Data and Chance (20\%) (Mullis et al., 2005). TIMSS uses item response theory (IRT) in combination with conditioning and multiple imputation to summarize students' total mathematics and sub-domain achievement on a scale with a mean of 500 and a standard deviation of 100, and a set of five plausible values are provided to account for the fact that not all students are administered all test items (Foy et al., 2008). HLM multilevel regression modeling software was used so that all five plausible values representing students' total mathematics achievement were used appropriately in the analyses.

\section{Teaching for conceptual understanding measures}

The teaching for conceptual understanding measures used to address the research questions were derived from a sub-set of the questions relating to teachers' self-reported instructional practices in the mathematics classroom (Mullis et al., 2008). Specifically, six of the available 
Table 1 Comparisons between reported sample statistics and analysis sample statistics

\begin{tabular}{|c|c|c|c|c|c|c|c|c|c|}
\hline & & \multicolumn{2}{|l|}{ U.S. } & \multicolumn{2}{|l|}{ Korea } & \multicolumn{2}{|l|}{ Japan } & \multicolumn{2}{|l|}{ Singapore } \\
\hline & & $\begin{array}{l}\text { Reported } \\
\text { sample }^{\mathrm{a}}\end{array}$ & $\begin{array}{l}\text { Analysis } \\
\text { sample }\end{array}$ & $\begin{array}{l}\text { Reported } \\
\text { sample }^{\mathrm{a}}\end{array}$ & $\begin{array}{l}\text { Analysis } \\
\text { sample }\end{array}$ & $\begin{array}{l}\text { Reported } \\
\text { sample }^{\mathrm{a}}\end{array}$ & $\begin{array}{l}\text { Analysis } \\
\text { sample }\end{array}$ & $\begin{array}{l}\text { Reported } \\
\text { sample }^{\mathrm{a}}\end{array}$ & $\begin{array}{l}\text { Analysis } \\
\text { sample }\end{array}$ \\
\hline \multirow[t]{2}{*}{ Sample Size } & \# Students & 7377 & 3255 & 4240 & 4102 & 4312 & 2719 & 4599 & 2270 \\
\hline & \# Schools & 239 & 217 & 150 & 150 & 146 & 107 & 164 & 160 \\
\hline \multirow[t]{2}{*}{ Achievement } & Mean & 508 & 507 & 597 & 597 & 570 & 567 & 593 & 596 \\
\hline & SD & 77 & 75 & 92 & 91 & 85 & 85 & 93 & 90 \\
\hline \multirow{6}{*}{$\begin{array}{l}\text { Percentage of students whose teachers asked them to do } \\
\text { the following in about half the lessons or more }\end{array}$} & Interpret data in tables, charts or graphs & $16 \%$ & $15 \%$ & $30 \%$ & $29 \%$ & $23 \%$ & $21 \%$ & $9 \%$ & $9 \%$ \\
\hline & $\begin{array}{l}\text { Write equations and functions to represent } \\
\text { relationships }\end{array}$ & $46 \%$ & $41 \%$ & $64 \%$ & $66 \%$ & $63 \%$ & $63 \%$ & $39 \%$ & $39 \%$ \\
\hline & $\begin{array}{l}\text { Apply facts, concepts and procedures to } \\
\text { solve routine problems }\end{array}$ & $81 \%$ & $80 \%$ & $88 \%$ & $87 \%$ & $66 \%$ & $63 \%$ & $65 \%$ & $66 \%$ \\
\hline & $\begin{array}{l}\text { Relate what they are learning in } \\
\text { mathematics to their daily lives }\end{array}$ & $57 \%$ & $61 \%$ & $56 \%$ & $54 \%$ & $20 \%$ & $22 \%$ & $34 \%$ & $32 \%$ \\
\hline & $\begin{array}{l}\text { Decide on their own procedures for solving } \\
\text { complex problems }\end{array}$ & $44 \%$ & $44 \%$ & $57 \%$ & $59 \%$ & $21 \%$ & $20 \%$ & $21 \%$ & $21 \%$ \\
\hline & $\begin{array}{l}\text { Work on problems for which there is no } \\
\text { immediately obvious method of solution }\end{array}$ & $22 \%$ & $24 \%$ & $27 \%$ & $27 \%$ & $23 \%$ & $18 \%$ & $10 \%$ & $8 \%$ \\
\hline
\end{tabular}


items were used to represent teachers' practices related to teaching for conceptual understanding. As discussed in the previous section, academic achievement has been shown to relate to instructional practices that help students develop conceptual understanding. TIMSS developed the set of teacher practice items in part by drawing on research on these issues (Schmidt and Cogan, 1996), particularly work by Prawat (1989a; 1989b) on the aspects of teaching that promote conceptual understanding, such as analyzing how students explain and solve problems, and giving students opportunities to engage with fundamental concepts. TIMSS developers used three of these six items in the 1999 administration as part of an index of Teachers' Emphasis on Mathematics Reasoning and Problem-solving (Mullis et al., 2000).

Measured on a scale ranging from "Every or almost every lesson" (3) to "Never" (0), the following six items that asked teachers to report how often they asked students to do the following were used to represent teachers' practices related to teaching for conceptual understanding:

... write equations and functions to represent relationships

... interpret data in tables, charts or graphs

... apply facts, concepts and procedures to solve routine problems

... relate what they are learning in mathematics to their daily lives

... decide on their own procedures for solving complex problems

... work on problems for which there is no immediately obvious method of solution

Teachers' responses to the six individual items were used to represent teachers' practices related to teaching for conceptual understanding. While the TIMSS instructional practice items do not map neatly onto the constructs of conceptual versus procedural knowledge development, the six items used in this study were chosen to represent several key elements of teaching for conceptual understanding. "Writ[ing] equations and functions to represent relationships" gives students the opportunity to explicitly examine conceptual relationships, using the symbolic language of mathematics (Hiebert, 2003; Prawat, 1989a). When students "relate what they are learning to their daily lives," they must transfer mathematical knowledge to a real-world context and connect different pieces of information (Hiebert and Lefevre, 1987). To "interpret data in tables, charts or graphs," "apply facts, concepts and procedures to solve routine problems," and "decide on their own procedures for solving complex problems," students must select the appropriate procedure and use it correctly for the given context (Hiebert and Lefevre, 1987). When students select their own methods of solution, the teacher also has an opportunity to observe students' thought processes and misconceptions (Hiebert and Grouws, 2007; Prawat, 1989a). Taking these problemsolving skills a step further, when students "work on problems for which there is no immediately obvious method of solution," they grapple with problems in which they have incomplete information or skills, creating a productive opportunity for growth (Hiebert and Grouws, 2007). In contrast, TIMSS instructional practice items representing activities that focus on procedural knowledge development were not included in this study (e.g., "memorize formulas and procedures" and "practice adding, subtracting, multiplying and dividing without using a calculator" (Mullis et al., 2008)). 
The authors explored the creation of a composite variable across all six items since composites have the advantage of providing a more comprehensive measure of the construct when compared to a single variable (DeVellis, 2012). However, principal axis factoring (PAF) indicated that the composite was not unidimensional across countries. Specifically, the six items split across two or three factors in the four countries. The frequency with which teachers asked students to "relate what they are learning in mathematics to their daily lives," "decide on their own procedures for solving complex problems" and "work on problems for which there is no immediately obvious method of solution" loaded on a single factor in all four countries. The reliability of the three-item scale ranged from 0.6 in Korea and Singapore to 0.7 in the U.S. and Japan. The remaining three items, the frequency with which teachers asked their students to "interpret data in tables, charts or graphs," "write equations and functions to represent relationships" and "apply facts, concepts and procedures to solve routine problems" loaded on a single factor in the U.S., Japan, and Singapore, but across two factors in Korea. The reliability of this scale was lower than optimal, ranging from .4 in the U.S. and Korea to .5 in Singapore and .7 in Japan. Based on the dimensionality of the items across countries and their lack of alignment with a theoretical construct, a composite variable was not created and teachers' responses to the six items were used individually in the analyses to represent teachers' practices related to teaching for conceptual understanding.

\section{Student and school covariates}

As student and school characteristics have been found to be associated with academic achievement, covariates measured at the student and school levels were included in the analyses. The purpose of the covariates was to account for student-to-student, and school-to-school differences that were unrelated to teachers' instructional practices. The student-level covariates included characteristics that prior research has linked with achievement: students' gender (Else-Quest et al., 2010; Liu and Wilson, 2009; Robinson and Lubienski, 2011), home background (Henderson and Berla, 1994; Berliner, 2006; Schreiber, 2002; Sirin, 2005; Votruba-Drzal, 2006; Yeung et al., 2002), and attitudes toward and beliefs about mathematics (Choi and Chang, 2011; Ho et al., 2000; Ma and Kishor, 1997; Singh et al., 2002). Likewise, the socioeconomic status of the school has been found to be associated with outcomes for individual students (Rothstein, 2004; Rumberger and Palardy, 2005).

Students' gender was included as a covariate $($ male $=1$, female $=0)$ at the student level and multiple student-level measures were combined to create a composite variable to represent students' home resources and family background. The home background composite was created from several related questions: home educational resources

Table 2 Reliabilities (a) for composite covariates

\begin{tabular}{|c|c|c|c|c|}
\hline & $\begin{array}{l}\text { U.S. } \\
\text { a }\end{array}$ & $\begin{array}{l}\text { Korea } \\
\mathbf{a}\end{array}$ & $\begin{array}{l}\text { Japan } \\
\mathbf{a}\end{array}$ & $\begin{array}{l}\text { Singapore } \\
\mathbf{a}\end{array}$ \\
\hline Home Background Composite & 0.65 & 0.56 & 0.67 & 0.62 \\
\hline Positive Affect Toward Mathematics Index (PAT-M) ${ }^{\dagger}$ & 0.86 & 0.89 & 0.84 & 0.88 \\
\hline Self-Confidence in Learning Mathematics Index $(\mathrm{SCM})^{\dagger}$ & 0.84 & 0.86 & 0.78 & 0.82 \\
\hline Students' Valuing Mathematics Index $(\mathrm{SVM})^{\dagger}$ & 0.73 & 0.74 & 0.70 & 0.76 \\
\hline
\end{tabular}

${ }^{\dagger}$ Source: Martin \& Preuschoff, 2008. 
(possession of a calculator, study desk, and dictionary), number of books in the home, and parents' highest education. The inter-relatedness of the items was confirmed using PAF and within each country, a standardized factor score with a mean of 0 and a standard deviation of 1 was created to represent students' home background. The reliability of the student home background composite is shown in Table 2 for each country. Also, to account for school-to-school differences related to the economic resources available in students' homes, the student home background composite was aggregated to the school level and included as a school-level covariate.

In an effort to control for student-to-student differences in attitudes toward and perceptions about mathematics, perceptions about their own ability in mathematics, as well differences in motivation to learn, three composite indices provided in the TIMSS student database were included as covariates in the analyses. The indices measured students' Positive Affect Toward Mathematics (PAT-M), students' Self-Confidence in Learning Mathematics (SCM) and Students' Valuing Mathematics (SVM) and were created by computing the mean of the student's scores on the constituent items (Martin and Preuschoff, 2008). The response categories for the items used to create the indices were agree a lot $=1$, agree a little $=2$, disagree a little $=3$, and disagree a lot $=4$. On each index, students were classified into low, medium and high based on the mean across the constituent items. Subsequently, a categorical variable was created in which students with a mean score of 2 or lower received a classification of high $(+1)$; students with mean scores greater than 2 but lower than 3 received a classification of medium (0); and students with scores of 3 or more received a low (-1) classification (Martin and Preuschoff, 2008). Since the three indices were categorical, two dummy variables were created for each index in which the high $(+1)$ group was the reference group for all comparisons. The categorical versions of the indices were used in the models because these characteristics were included as student-level covariates and were not central to addressing the research questions. The reliabilities of the three indices across countries are shown in Table 2.

\section{Analysis procedures}

Analyses were conducted separately by country and included teacher-level analyses (research question 1) and student-level analyses (research question 2). To address the first research question, descriptive statistics were calculated using teachers' responses to the six individual teaching for conceptual understanding items and the results were represented both graphically and numerically. In addition, one-way ANOVAs with Bonferroni post hoc tests were conducted to examine whether the frequency of teaching for conceptual understanding in the U.S. was significantly different from the frequency in the East Asian countries. The descriptive statistics and ANOVAs allowed comparisons among countries with respect to mathematics teachers' use of instructional practices that support conceptual understanding. In each country, sampling weights were used to make adjustments for non-response and to ensure that subgroups of the sample were properly represented in the estimation of population parameters (Joncas, 2008). Since the descriptive analyses and ANOVAs were based on teacher data, the mathematics teacher sampling weight (MATWGT) was applied to generate accurate estimates in each country. 
To address the second research question, a series of multilevel linear regression models was formulated for each country. HLM software was chosen so that all five plausible values could be analyzed appropriately and so that the sampling weights could be applied at the appropriate level. In the series of models, students' achievement on the TIMSS mathematics assessment, represented by five plausible values, was regressed on teachers' practices related to teaching for conceptual understanding along with the student and school covariates. Multilevel regression procedures ensured that the statistical dependence among students within schools was accounted for by the complex residual structure thereby producing correct estimates of the standard errors associated with the regression coefficients; allowed student, teacher and school characteristics to be included in a single model to predict students' mathematics achievement; and allowed all five plausible values to be handled simultaneously (Raudenbush and Bryk, 2002). The multilevel regression analyses required the calculation of student population estimates within each country and so the authors followed the guidelines set forth in the TIMSS documentation and applied the student sampling weight (TOTWGT) at the student level. Since this weight includes the probability of both the school and student being selected from the population, no weights were required at the school level (Joncas, 2008).

At the first stage, an unconditional (or null) two-level regression model was specified for each country. This model was used to partition the total variability in mathematics achievement scores into within- and between-school variance components. These unconditional variance components were used to estimate the degree of statistical dependence (nesting) among students within schools for each country, as indicated by the intra-class correlation coefficient (ICC) and served as a comparison for subsequent models that included teachers' instructional practices as well as the student and school covariates. For each country, the unconditional model used to calculate the ICC was as follows:

$$
Y_{i j}=\beta_{0 j}+r_{i j} \text { and } \beta_{0 j}=\gamma_{00}+u_{0 j}
$$

At the second stage, teachers' practices related to teaching for conceptual understanding and the student and school covariates were included in the model to predict students' mathematics scores. The six individual teaching for conceptual understanding items were added to the models separately, thereby allowing the association between each one and mathematics scores to be examined independently. In each country, the level-1 model included the student covariates:

$$
\begin{aligned}
Y_{i j}= & \beta_{0 j}+\beta_{1 j}(\text { Gender })_{i j}+\beta_{2 j}(\text { Home Background Composite })_{i j}+\beta_{3 j}(\text { PAT-M D } 1)_{i j} \\
& +\beta_{4 j}(\text { PAT-M D } 2)_{i j}+\beta_{5 j}(\text { SVM D } 1)_{i j}+\beta_{6 j}(\text { SVM D } 2)_{i j}+\beta_{7 j}(\text { SCM D } 1)_{i j} \\
& +\beta_{8 j}(\text { SCM D } 2)_{i j}+r_{i j}
\end{aligned}
$$

In this model, the mathematics score for student $i$ in school $j\left(Y_{i j}\right)$ was predicted by the linear combination of student covariates and a random student effect, $r_{i j}$. The regression coefficients $\beta_{1}$ through $\beta_{8}$ represent the association between each covariate and mathematics achievement, holding all other predictors in the model constant. The level-1 covariates were entered into the model uncentered since they were dichotomous (i.e., gender), standardized to have a mean of 0 and a standard deviation of 1 (i.e., home background composite), or were coded as dichotomous dummy variables (i.e., PAT-M, SVM, and SCM). 
At level-2, the aggregated student home background composite was included as a school covariate along with the teaching for conceptual understanding measures, each added separately. In each country, six level-2 models were formulated, one for each of the six teaching for conceptual understanding items, as follows:

$$
\begin{aligned}
\beta_{0 j}= & \gamma_{00}+\gamma_{01}(\text { Aggregated HBI })_{j} \\
& +\gamma_{02}(\text { Teaching for Conceptual Understanding Measure })_{j}+u_{0 j}
\end{aligned}
$$

In each of the six intercept-only models, the $\gamma_{02}$ regression coefficient represented the association between a particular teaching for conceptual understanding measure and mathematics test scores, holding all covariates in the model constant. The individual teaching for conceptual understanding measures were entered into the model uncentered. The percentage of economically disadvantaged students in the school was grand mean centered around the mean for all schools.

During the model development phase, the significance and reliability of the variability in the level-1 regression coefficients associated with the student covariates across schools was evaluated using McCoach's guidelines (2010). With some exceptions, the level-1 regression coefficients were found to be constant across schools and so these regression coefficients were fixed. However, in the U.S. and Japan, the relationships between mathematics test scores and gender, and between test scores and the SVM index, were not constant across schools. Also, in Japan, the relationship between mathematics test scores and the SCM index was not constant across schools. Additional exploratory analyses revealed that the variability in these relationships across schools was not related to the level-2 variables included in the analyses, the teaching for conceptual understanding measures and the percent of economically disadvantaged students in the school covariate. Therefore, in the final models, the slopes associated with these level-1 variables in the U.S. and Japan were allowed to vary randomly across schools, but no level-2 predictors were included in the models to predict that variability. In all other countries and for the other level-1 variables in the U.S. and Japan models, the level-1 slopes were fixed. For the fixed $P$ level-1 slopes, the models were:

$$
\beta_{\mathrm{pj}}=\gamma_{\mathrm{p} 0}
$$

And, for the random $P$ level-1 slopes (e.g., for the gender and SVM slopes in the U.S. and Japan, and for the SCM slope in Japan) the models were:

$$
\beta_{\mathrm{pj}}=\gamma_{\mathrm{p} 0}+u_{p j}
$$

Comparisons between the fixed effects across models with different varying slopes is deemed to be appropriate since allowing slopes to vary randomly has little effect on the fixed effects or the standard errors associated with these fixed effects (Raudenbush and Bryk, 2002).

For each country, the regression coefficients and variance components from these models were evaluated to examine whether teaching for conceptual understanding predicted students' mathematics achievement within each country, after controlling for student characteristics, and whether these relationships varied across countries. 


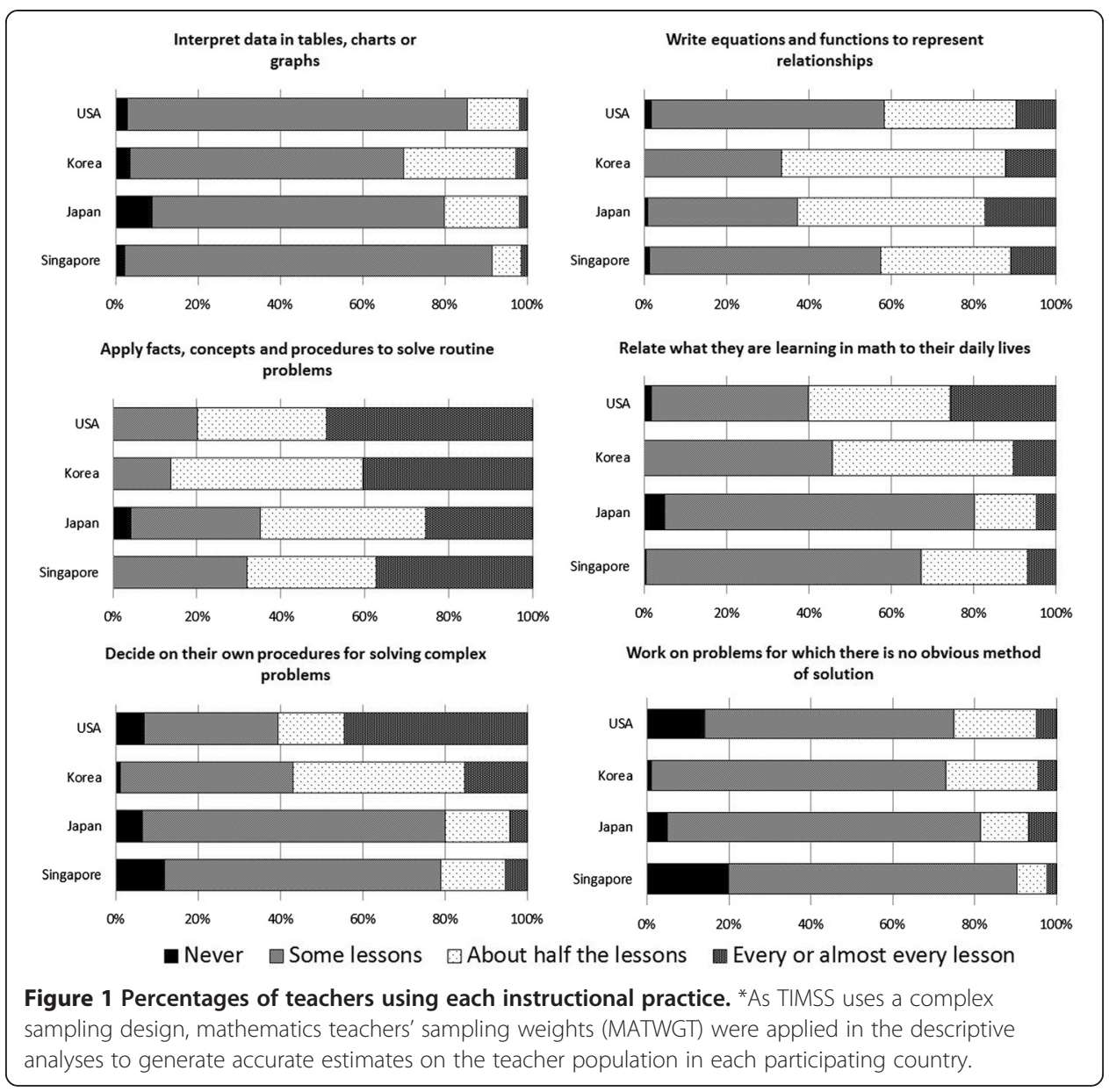

\section{Results}

\section{Patterns of teaching for conceptual understanding}

Figure 1 and Table 3 summarize the weighted percentages of teachers in the four countries that reported using the six individual measures of teaching for conceptual understanding (never (0), some lessons (1), about half the lessons (3), and every or almost every lesson(4)) and the descriptive statistics (mean, standard error of the mean, and standard deviation), respectively. Comparing across the six individual measures of teaching for conceptual understanding in all four countries, the largest percentage of mathematics teachers reported that they spent time in every or almost every lesson having their students apply facts, concepts and procedures to solve routine problems (48.8\% in the U.S., $42.7 \%$ in Korea, 27.1\% in Japan, and 34.4\% in Singapore). The lowest percentage of mathematics teachers in all four countries spent time in every, or almost every lesson having their students interpret data in tables, charts or graphs (approximately $1.9 \%$ in the U.S., $2.7 \%$ in Korea, $2.8 \%$ in Japan, and $1.3 \%$ in Singapore). In general, the results in Figure 1 and Table 3 show that there is variability among the four countries in how teachers teach for conceptual understanding.

The results of the ANOVAs in Table 3 show that for each item, there were significant differences among at least two of the country means, even with a conservative alpha of $.05 / 6$ or .008 . Focusing on how the U.S. compared to the other countries on the 
Table 3 Means and standard deviations for the measures of teaching for conceptual understanding ${ }^{a}$

How often do you ask students to...

\begin{tabular}{|c|c|c|c|c|c|c|c|}
\hline & & $\begin{array}{l}\ldots \text { interpret data in tables, } \\
\text { charts or graphs }\end{array}$ & $\begin{array}{l}\ldots \text { write equations and } \\
\text { functions to represent } \\
\text { relationships }\end{array}$ & $\begin{array}{l}\ldots \text { apply facts, concepts } \\
\text { and procedures to solve } \\
\text { routine problems }\end{array}$ & $\begin{array}{l}\text {...relate what they are } \\
\text { learning in mathematics } \\
\text { to their daily lives }\end{array}$ & $\begin{array}{l}\text {... decide on their own } \\
\text { procedures for solving } \\
\text { complex problems }\end{array}$ & $\begin{array}{l}\ldots \text { work on problems for } \\
\text { which there is no immediately } \\
\text { obvious method of solution }\end{array}$ \\
\hline \multirow[t]{3}{*}{ U.S. } & Mean & 1.14 & 1.49 & 2.29 & 1.86 & 1.54 & 1.15 \\
\hline & S.E & 0.001 & 0.002 & 0.002 & 0.003 & 0.002 & 0.002 \\
\hline & Std. Dev. & 0.46 & 0.69 & 0.78 & 0.83 & 0.75 & 0.72 \\
\hline \multirow[t]{3}{*}{ Korea } & Mean & 1.28 & 1.78 & 2.30 & 1.65 & 1.74 & 1.30 \\
\hline & S.E & 0.004 & 0.004 & 0.004 & 0.004 & 0.005 & 0.004 \\
\hline & Std. Dev. & 0.57 & 0.65 & 0.68 & 0.67 & 0.74 & 0.58 \\
\hline \multirow[t]{3}{*}{ Japan } & Mean & 1.16 & 1.80 & 1.85 & 1.23 & 1.18 & 1.19 \\
\hline & S.E & 0.003 & 0.004 & 0.005 & 0.003 & 0.003 & 0.004 \\
\hline & Std. Dev. & 0.60 & 0.75 & 0.88 & 0.62 & 0.61 & 0.63 \\
\hline \multirow[t]{3}{*}{ Singapore } & Mean & 1.09 & 1.48 & 2.00 & 1.38 & 1.13 & 0.88 \\
\hline & S.E & 0.01 & 0.018 & 0.021 & 0.016 & 0.017 & 0.015 \\
\hline & Std. Dev. & 0.38 & 0.69 & 0.83 & 0.61 & 0.66 & 0.59 \\
\hline \multicolumn{8}{|c|}{ ANOVA $(d f=3,630)^{b}$} \\
\hline & $\mathrm{F}$ & 4.18 & 9.67 & 11.17 & 24.40 & 25.73 & 11.92 \\
\hline & Sig. & $<.01$ & $<.001$ & $<.001$ & $<.001$ & $<.001$ & $<.001$ \\
\hline
\end{tabular}

as TIMSS uses a complex sampling design, mathematics teachers' sampling weights (MATWGT) were applied in the descriptive analyses to generate accurate estimates in each participating country.

${ }^{\mathrm{b}}$ For the ANOVA, the alpha level was reduced to.05/6 or .008 to adjust for conducting six tests. 
frequency of teaching for conceptual understanding, the post hoc tests indicate patterns in the differences. First, teachers in the U.S. reported that they had their students engage in four of the six practices significantly more frequently than teachers in some of the other countries. Specifically, mathematics teachers in the U.S. $(M=1.86, S D=0.83)$ reported significantly higher rates for having their students relate what they are learning in mathematics to their daily lives than teachers in Japan $(\mathrm{M}=1.26, \mathrm{SD}=0.62)$, Korea $(\mathrm{M}=1.65, \mathrm{SD}=0.67)$, or Singapore $(\mathrm{M}=1.38, \mathrm{SD}=0.61)$. Likewise, the post hoc tests showed that teachers in the U.S. $(\mathrm{M}=2.29, \mathrm{SD}=0.78)$ reported having their students apply facts, concepts and procedures to solve routine problems significantly more frequently than teachers in Japan $(\mathrm{M}=1.85, \mathrm{SD}=0.88)$ or Singapore $(\mathrm{M}=2.00, \mathrm{SD}=0.83)$. Teachers in the U.S. $(\mathrm{M}=1.54, \mathrm{SD}=0.75)$ also had their students decide on their own procedures for solving complex problems significantly more often than teachers in Japan $(M=1.18, S D=0.61)$ or Singapore $(M=1.13, S D=0.66)$. Finally, teachers in the U.S. $(\mathrm{M}=1.15, \mathrm{SD}=0.72)$ reported having their students work on problems for which there is no immediately obvious method of solution significantly more frequently than teachers in Singapore $(\mathrm{M}=0.88, \mathrm{SD}=0.59)$.

This pattern was reversed for the practice of having students write equations and functions to represent relationships and interpret data in tables, charts or graphs. Teachers in the U.S. $(\mathrm{M}=1.49, \mathrm{SD}=0.69)$ were significantly less likely to have their students write equations and functions to represent relationships than teachers in either Japan $(\mathrm{M}=1.80, \mathrm{SD}=0.75)$ or Korea $(\mathrm{M}=1.78, \mathrm{SD}=0.65)$. Although the frequency of teachers having their students interpret data in tables, charts or graphs was low in both countries (see Figure 1), teachers in the U.S. $(M=1.14, \mathrm{SD}=0.46)$ were significantly less likely than teachers in Korea $(\mathrm{M}=1.28, \mathrm{SD}=0.57)$ to engage in this practice.

These patterns across the four countries support the findings from classroom observation studies (Hiebert et al., 2005; VanTassel-Baska et al., 2008; Whitman and Lai, 1990) that there is variability in teachers' use of the instructional practices measured on the TIMSS teacher survey across countries.

\section{Teaching for conceptual understanding and mathematics test scores}

Tables 4, 5, 6, and 7 present the regression coefficients associated with the six individual teaching for conceptual understanding measures (Models 1-6) for predicting students' total mathematics test scores in the U.S., Korea, Japan, and Singapore, respectively. Since the student and school covariates are included in Models 1 through 6, the tables also present those regression coefficients. Using the standard deviation of students' mathematics scores in the sample, the coefficients were transformed into predicted standardized differences by dividing the regression coefficient by the standard deviation of the outcome variable (see Table 1). For example, if an independent variable $X$ is associated with a regression coefficient $b$ for predicting the outcome variable $Y$, the standardized regression coefficient is interpreted as the predicted standard deviation change in $Y$ for a one unit increase in $X$, holding all else constant. In this case, a one unit increase in $X$ corresponds to increasing teaching for conceptual understanding practices from never to some lessons, from some lessons to about half the lessons, or from about half the lessons to every or almost every lesson. Subsequent to the interpretation of the fixed effects, the percentage of variance explained by the models is discussed. 
Table 4 U.S.: Relationship between measures of teaching for conceptual understanding and mathematics achievement

\begin{tabular}{|c|c|c|c|c|c|c|}
\hline & $\begin{array}{l}\text { Model } 1 \\
\text { Coeff.(s.e.) }\end{array}$ & $\begin{array}{l}\text { Model } 2 \\
\text { Coeff.(s.e.) }\end{array}$ & $\begin{array}{l}\text { Model } 3 \\
\text { Coeff.(s.e.) }\end{array}$ & $\begin{array}{l}\text { Model } 4 \\
\text { Coeff.(s.e.) }\end{array}$ & $\begin{array}{l}\text { Model } 5 \\
\text { Coeff.(s.e.) }\end{array}$ & $\begin{array}{l}\text { Model } 6 \\
\text { Coeff.(s.e.) }\end{array}$ \\
\hline \multicolumn{7}{|l|}{ Fixed components } \\
\hline Intercept & $515.17(7.26)^{\mathrm{a}}$ & $498.91(6.17)^{\mathrm{a}}$ & $516.44(7.68)^{a}$ & $519.66(5.64)^{\mathrm{a}}$ & $505.49(5.78)^{a}$ & $511.77(4.84)^{\mathrm{a}}$ \\
\hline \multicolumn{7}{|l|}{ Student level variables } \\
\hline Gender ( male $=1$, female $=0$ ) $\dagger$ & $5.95(2.27)^{c}$ & $5.83(2.28)^{c}$ & $5.92(2.28)^{c}$ & $5.93(2.27)^{c}$ & $5.99(2.27)^{c}$ & $5.92(2.27)^{c}$ \\
\hline Home Background Composite & $6.20(1.32)^{a}$ & $6.21(1.32)^{\mathrm{a}}$ & $6.20(1.32)^{a}$ & $6.20(1.32)^{a}$ & $6.20(1.32)^{a}$ & $6.20(1.32)^{a}$ \\
\hline Index: Positive Affects (high v. low) & $-2.76(2.86)$ & $-2.54(2.86)$ & $-2.80(2.86)$ & $-2.80(2.86)$ & $-2.73(2.86)$ & $-2.76(2.86)$ \\
\hline Index: Positive Affects (high v. med) & $-0.14(2.70)$ & $0.07(2.68)$ & $-0.14(2.70)$ & $-0.15(2.70)$ & $-0.09(2.69)$ & $-0.10(2.7)$ \\
\hline Index: Valuing Mathematics (high v. low) $†$ & $-0.75(6.14)$ & $-0.53(6.12)$ & $-0.70(6.14)$ & $-0.70(6.14)$ & $-0.72(6.14)$ & $-0.61(6.14)$ \\
\hline Index: Valuing Mathematics (high v. med) & $1.86(3.03)$ & $1.90(3.03)$ & $1.89(3.02)$ & 1.87(3.02) & $1.87(3.03)$ & $1.91(3.02)$ \\
\hline Index: Self-confidence (high v. low) & $-47.33(3.32)^{a}$ & $-47.40(3.31)^{\mathrm{a}}$ & $-47.32(3.32)^{a}$ & $-47.30(3.32)^{a}$ & $-47.29(3.32)^{a}$ & $-47.34(3.32)^{\mathrm{a}}$ \\
\hline Index: Self-confidence (high v. med) & $-30.52(2.46)^{a}$ & $-30.58(2.46)^{\mathrm{a}}$ & $-30.52(2.47)^{a}$ & $-30.51(2.47)^{\mathrm{a}}$ & $-30.50(2.46)^{a}$ & $-30.52(2.46)^{\mathrm{a}}$ \\
\hline \multicolumn{7}{|l|}{ Teacher/School level variables } \\
\hline$\%$ of students in school from economically disadvantaged homes & $71.26(5.84)^{\mathrm{a}}$ & $66.87(5.72)^{\mathrm{a}}$ & $71.47(5.82)^{\mathrm{a}}$ & $71.48(5.96)^{\mathrm{a}}$ & $72.06(5.81)^{\mathrm{a}}$ & $71.18(5.77)^{\mathrm{a}}$ \\
\hline
\end{tabular}

Teaching for Conceptual Understanding Items

How often do you ask students to...

$\ldots$ interpret data in tables, charts or graphs

$7.65(7.47)$

... write equations and functions to represent relationships

$24.78(4.53)^{\mathrm{a}}$

... apply facts, concepts and procedures to solve routine problems

$1.13(4.54)$

... relate what they are learning in mathematics to their daily lives

$0.09(2.77)$

... decide on their own procedures for solving complex problems

$9.49(3.24)^{b}$

work on problems for which there is no immediately obvious method of solution

${ }^{\mathrm{a}}$ Coefficients are statistically significant at $p<.001,{ }^{\mathrm{b}}$ Coefficients are statistically significant at $p<.01,{ }^{\mathrm{C}}$ Coefficients are statistically significant at $p<.05$.

Student sampling weights (TOTWGT) were used at level-1 in all analyses.

tThe level-1 slope associated with this variable was allowed to vary randomly across schools. No predictors were included to explain the variability in the slope. 
Table 5 Korea: Relationship between measures of teaching for conceptual understanding and mathematics achievement

\begin{tabular}{|c|c|c|c|c|c|c|}
\hline & $\begin{array}{l}\text { Model } 1 \\
\text { Coeff.(s.e.) }\end{array}$ & $\begin{array}{l}\text { Model } 2 \\
\text { Coeff.(s.e.) }\end{array}$ & $\begin{array}{l}\text { Model } 3 \\
\text { Coeff.(s.e.) }\end{array}$ & $\begin{array}{l}\text { Model } 4 \\
\text { Coeff.(s.e.) }\end{array}$ & $\begin{array}{l}\text { Model } 5 \\
\text { Coeff.(s.e.) }\end{array}$ & $\begin{array}{l}\text { Model } 6 \\
\text { Coeff.(s.e.) }\end{array}$ \\
\hline \multicolumn{7}{|l|}{ Fixed components } \\
\hline Intercept & $680.82(4.75)^{\mathrm{a}}$ & $672.97(6.2)^{\mathrm{a}}$ & $679.57(7.11)^{\mathrm{a}}$ & $674.32(5.49)^{\mathrm{a}}$ & $669.16(4.77)^{a}$ & $675.10(5.21)^{\mathrm{a}}$ \\
\hline \multicolumn{7}{|l|}{ Student level variables } \\
\hline Gender ( male $=1$, female $=0)+$ & $-4.46(2.65)$ & $-4.51(2.66)$ & $-4.64(2.63)$ & $-4.51(2.65)$ & $-4.60(2.68)$ & $-4.44(2.67)$ \\
\hline Home Background Composite & $18.10(1.26)^{\mathrm{a}}$ & $18.10(1.26)^{\mathrm{a}}$ & $18.10(1.26)^{\mathrm{a}}$ & $18.1(1.26)^{\mathrm{a}}$ & $18.10(1.26)^{\mathrm{a}}$ & $18.09(1.26)^{\mathrm{a}}$ \\
\hline Index: Positive Affects (high v. low) & $-20.96(3.72)^{a}$ & $-20.91(3.72)^{\mathrm{a}}$ & $-20.80(3.74)^{\mathrm{a}}$ & $-20.89(3.72)^{\mathrm{a}}$ & $-20.88(3.72)^{a}$ & $-20.85(3.72)^{a}$ \\
\hline Index: Positive Affects (high v. med) & $-11.12(3.4)^{\mathrm{b}}$ & $-11.09(3.41)^{\mathrm{b}}$ & $-11.07(3.42)^{\mathrm{b}}$ & $-11.05(3.4)^{b}$ & $-11.07(3.4)^{b}$ & $-11.08(3.41)^{b}$ \\
\hline Index: Valuing Mathematics (high v. low) $\dagger$ & $-16.71(4.47)^{a}$ & $-16.80(4.46)^{\mathrm{a}}$ & $-16.78(4.45)^{\mathrm{a}}$ & $-16.85(4.46)^{\mathrm{a}}$ & $-16.76(4.46)^{a}$ & $-16.88(4.45)^{a}$ \\
\hline Index: Valuing Mathematics (high v. med) & $-8.27(2.64)^{b}$ & $-8.37(2.64)^{b}$ & $-8.33(2.64)^{b}$ & $-8.41(2.63)^{b}$ & $-8.36(2.63)^{b}$ & $-8.42(2.64)^{b}$ \\
\hline Index: Self-confidence (high v. low) & $-101.49(3.38)^{\mathrm{a}}$ & $-101.51(3.39)^{a}$ & $-101.65(3.40)^{\mathrm{a}}$ & $-101.50(3.39)^{\mathrm{a}}$ & $-101.55(3.39)^{a}$ & $-101.56(3.39)^{\mathrm{a}}$ \\
\hline Index: Self-confidence (high v. med) & $-45.13(3.15)^{\mathrm{a}}$ & $-45.19(3.16)^{\mathrm{a}}$ & $-45.35(3.17)^{\mathrm{a}}$ & $-45.19(3.16)^{a}$ & $-45.23(3.16)^{\mathrm{a}}$ & $-45.22(3.16)^{a}$ \\
\hline \multicolumn{7}{|l|}{ Teacher/School level variables } \\
\hline$\%$ of students in school from economically disadvantaged homes & $41.25(6.98)^{a}$ & $41.43(7.01)^{\mathrm{a}}$ & $41.34(6.91)^{\mathrm{a}}$ & $41.19(6.98)^{\mathrm{a}}$ & $41.23(7.04)^{\mathrm{a}}$ & $41.31(6.96)^{a}$ \\
\hline \multicolumn{7}{|l|}{ Teaching for Conceptual Understanding Items } \\
\hline \multicolumn{7}{|l|}{ How often do you ask students to... } \\
\hline ... interpret data in tables, charts or graphs & $-7.45(2.86)^{\mathrm{c}}$ & & & & & \\
\hline ... write equations and functions to represent relationships & & $-0.93(2.69)$ & & & & \\
\hline ... apply facts, concepts and procedures to solve routine problems & & & $-3.57(2.84)$ & & & \\
\hline ... relate what they are learning in mathematics to their daily lives & & & & $-1.82(2.54)$ & & \\
\hline ... decide on their own procedures for solving complex problems & & & & & $1.26(2.36)$ & \\
\hline ... work on problems for which there is no immediately obvious method of solution & & & & & & $-2.94(3.19)$ \\
\hline
\end{tabular}

${ }^{\mathrm{a} C o e f f i c i e n t s}$ are statistically significant at $p<.001,{ }^{\mathrm{b}}$ Coefficients are statistically significant at $p<.01,{ }^{\mathrm{c}}$ Coefficients are statistically significant at $p<.05$.

Student sampling weights (TOTWGT) were used at level-1 in all analyses. 
Table 6 Japan: Relationship between measures of teaching for conceptual understanding and mathematics achievement

\begin{tabular}{|c|c|c|c|c|c|c|}
\hline & $\begin{array}{l}\text { Model } 1 \\
\text { Coeff.(s.e.) }\end{array}$ & $\begin{array}{l}\text { Model } 2 \\
\text { Coeff.(s.e.) }\end{array}$ & $\begin{array}{l}\text { Model } 3 \\
\text { Coeff.(s.e.) }\end{array}$ & $\begin{array}{l}\text { Model } 4 \\
\text { Coeff.(s.e.) }\end{array}$ & $\begin{array}{l}\text { Model } 5 \\
\text { Coeff.(s.e.) }\end{array}$ & $\begin{array}{l}\text { Model } 6 \\
\text { Coeff.(s.e.) }\end{array}$ \\
\hline \multicolumn{7}{|l|}{ Fixed components } \\
\hline Intercept & $636.27(6.87)^{\mathrm{a}}$ & $635.90(9.54)^{\mathrm{a}}$ & $635.46(9.44)^{\mathrm{a}}$ & $633.38(8.55)^{\mathrm{a}}$ & $628.25(9.69)^{\mathrm{a}}$ & $624.35(8.76)^{a}$ \\
\hline \multicolumn{7}{|l|}{ Student level variables } \\
\hline Gender $($ male $=1$, female $=0$ ) $\dagger$ & $-1.69(3.27)$ & $-1.68(3.28)$ & $-1.68(3.27)$ & $-1.67(3.28)$ & $-1.64(3.28)$ & $-1.67(3.28)$ \\
\hline Home Background Composite & $13.52(1.71)^{\mathrm{a}}$ & $13.52(1.71)^{\mathrm{a}}$ & $13.52(1.71)^{\mathrm{a}}$ & $13.52(1.71)^{\mathrm{a}}$ & $13.52(1.71)^{\mathrm{a}}$ & $13.51(1.71)^{\mathrm{a}}$ \\
\hline Index: Positive Affects (high v. low) & $-18.75(4.48)^{\mathrm{a}}$ & $-18.76(4.49)^{a}$ & $-18.75(4.49)^{a}$ & $-18.75(4.49)^{a}$ & $-18.70(4.46)^{a}$ & $-18.67(4.48)^{\mathrm{a}}$ \\
\hline Index: Positive Affects (high v. med) & $-12.13(3.94)^{b}$ & $-12.14(3.95)^{b}$ & $-12.14(3.94)^{b}$ & $-12.13(3.94)^{b}$ & $-12.07(3.94)^{b}$ & $-12.10(3.94)^{b}$ \\
\hline Index: Valuing Mathematics (high v. low) $\dagger$ & $-21.65(5.45)^{\mathrm{a}}$ & $-21.64(5.44)^{\mathrm{a}}$ & $-21.63(5.44)^{a}$ & $-21.61(5.45)^{\mathrm{a}}$ & $-21.59(5.45)^{\mathrm{a}}$ & $-21.55(5.44)^{a}$ \\
\hline Index: Valuing Mathematics (high v. med) & $-7.05(3.19)^{c}$ & $-7.04(3.19)^{c}$ & $-7.04(3.19)^{c}$ & $-7.03(3.19)^{c}$ & $-7.03(3.19)^{c}$ & $-6.97(3.19)^{c}$ \\
\hline Index: Self-confidence (high v. low) & $-76.23(6.02)^{a}$ & $-76.22(6.03)^{a}$ & $-76.22(6.03)^{a}$ & $-76.21(6.03)^{\mathrm{a}}$ & $-76.20(6.03)^{\mathrm{a}}$ & $-76.25(6.04)^{\mathrm{a}}$ \\
\hline Index: Self-confidence (high v. med) & $-35.99(4.9)^{\mathrm{a}}$ & $-35.99(4.9)^{a}$ & $-35.99(4.91)^{\mathrm{a}}$ & $-35.99(4.9)^{\mathrm{a}}$ & $-36.05(4.9)^{a}$ & $-36.08(4.91)^{a}$ \\
\hline \multicolumn{7}{|l|}{ Teacher/School level variables } \\
\hline$\%$ of students in school from economically disadvantaged homes & $46.36(13.92)^{b}$ & $46.56(13.93)^{b}$ & $46.35(14.14)^{b}$ & $46.54(13.88)^{\mathrm{b}}$ & $45.87(13.88)^{\mathrm{b}}$ & $45.86(13.73)^{b}$ \\
\hline
\end{tabular}

Teaching for Conceptual Understanding Items

How often do you ask students to...

... interpret data in tables, charts or graphs

$-1.07(4.57)$

... write equations and functions to represent relationships

$-0.48(4.45)$

... apply facts, concepts and procedures to solve routine problems

$-0.23(3.82)$

... relate what they are learning in mathematics to their daily lives

$1.38(5.5)$

.. decide on their own procedures for solving complex problems

$5.76(6.88)$

work on problems for which there is no immediately obvious method of solution

$8.95(5.75)$

${ }^{a}$ Coefficients are statistically significant at $p<.001,{ }^{\mathrm{b}}$ Coefficients are statistically significant at $p<.01$, ${ }^{\mathrm{C}}$ Coefficients are statistically significant at $p<.05$.

Student sampling weights (TOTWGT) were used at level-1 in all analyses.

tThe level-1 slope associated with this variable was allowed to vary randomly across schools. No predictors were included to explain the variability in the slope. 
Table 7 Singapore: Relationship between measures of teaching for conceptual understanding and mathematics achievement

\begin{tabular}{|c|c|c|c|c|c|c|}
\hline & $\begin{array}{l}\text { Model } 1 \\
\text { Coeff.(s.e.) }\end{array}$ & $\begin{array}{l}\text { Model } 2 \\
\text { Coeff.(s.e.) }\end{array}$ & $\begin{array}{l}\text { Model } 3 \\
\text { Coeff.(s.e.) }\end{array}$ & $\begin{array}{l}\text { Model } 4 \\
\text { Coeff.(s.e.) }\end{array}$ & $\begin{array}{l}\text { Model } 5 \\
\text { Coeff.(s.e.) }\end{array}$ & $\begin{array}{l}\text { Model } 6 \\
\text { Coeff.(s.e.) }\end{array}$ \\
\hline \multicolumn{7}{|l|}{ Fixed components } \\
\hline Intercept & $606.19(7.91)^{\mathrm{a}}$ & $604.46(7.97)^{\mathrm{a}}$ & $619.59(9.55)^{\mathrm{a}}$ & $619.46(8.69)^{\mathrm{a}}$ & $603.36(5.96)^{\mathrm{a}}$ & $602.44(6.72)^{\mathrm{a}}$ \\
\hline \multicolumn{7}{|l|}{ Student level variables } \\
\hline Gender $($ male $=1$, female $=0$ ) & $3.66(2.46)$ & $3.62(2.45)$ & $3.68(2.46)$ & $3.67(2.46)$ & $3.67(2.46)$ & $3.72(2.46)$ \\
\hline Home Background Composite & $2.07(1.03)^{c}$ & $2.08(1.03)^{c}$ & $2.07(1.03)^{c}$ & $2.07(1.03)^{c}$ & $2.07(1.03)^{c}$ & $2.07(1.03)^{c}$ \\
\hline Index: Positive Affects (high v. low) & $-14.41(3.85)^{\mathrm{b}}$ & $-14.40(3.85)^{\mathrm{b}}$ & $-14.42(3.85)^{\mathrm{b}}$ & $-14.43(3.85)^{\mathrm{b}}$ & $-14.43(3.85)^{\mathrm{b}}$ & $-14.45(3.85)^{b}$ \\
\hline Index: Positive Affects (high v. med) & $-3.59(3.66)$ & $-3.59(3.66)$ & $-3.60(3.66)$ & $-3.60(3.66)$ & $-3.56(3.66)$ & $-3.59(3.66)$ \\
\hline Index: Valuing Mathematics (high v. low) & $-13.64(5.14)^{b}$ & $-13.60(5.14)^{b}$ & $-13.66(5.15)^{b}$ & $-13.63(5.14)^{\mathrm{b}}$ & $-13.60(5.14)^{b}$ & $-13.61(5.14)^{b}$ \\
\hline Index: Valuing Mathematics (high v. med) & $3.33(2.6)$ & $3.33(2.6)$ & $3.35(2.59)$ & $3.37(2.6)$ & $3.34(2.6)$ & $3.36(2.6)$ \\
\hline Index: Self-confidence (high v. low) & $-45.03(3.58)^{a}$ & $-45.01(3.58)^{a}$ & $-45.04(3.58)^{\mathrm{a}}$ & $-45.04(3.58)^{\mathrm{a}}$ & $-45.01(3.58)^{\mathrm{a}}$ & $-45.02(3.57)^{\mathrm{a}}$ \\
\hline Index: Self-confidence (high v. med) & $-26.19(2.41)^{\mathrm{a}}$ & $-26.18(2.4)^{\mathrm{a}}$ & $-26.20(2.41)^{\mathrm{a}}$ & $-26.21(2.41)^{\mathrm{a}}$ & $-26.21(2.41)^{\mathrm{a}}$ & $-26.21(2.41)^{a}$ \\
\hline \multicolumn{7}{|l|}{ Teacher/School level variables } \\
\hline$\%$ of students in school from economically disadvantaged homes & $117.66(5.94)^{\mathrm{a}}$ & $115.85(6.24)^{\mathrm{a}}$ & $119.53(6.51)^{\mathrm{a}}$ & $117.62(6.02)^{\mathrm{a}}$ & $117.48(6.15)^{\mathrm{a}}$ & $115.12(6.05)^{\mathrm{a}}$ \\
\hline
\end{tabular}

\section{Teaching for Conceptual Understanding Items}

How often do you ask students to...

... interpret data in tables, charts or graphs

$11.06(14.73)$

... write equations and functions to represent relationships

... apply facts, concepts and procedures to solve routine problems

... relate what they are learning in mathematics to their daily lives

$28.38(7.63)^{\mathrm{a}}$

$20.43(7.58)^{b}$

$-8.06(9.26)$

$10.97(10.76)$

.. work on problems for which there is no immediately obvious method of solution

$33.68(8.92)^{\mathrm{a}}$

${ }^{a}$ Coefficients are statistically significant at $p<.001,{ }^{\mathrm{b}}$ Coefficients are statistically significant at $p<.01$, ${ }^{\mathrm{C}}$ Coefficients are statistically significant at $p<.05$.

Sampling weights (TOTWGT) were used at level-1 in all analyses. 
For the U.S., Table 4 shows that the frequency with which teachers asked their students to write equations and functions to represent relationships $(\mathrm{b}=24.78$, standardized difference $=0.33, \mathrm{p}<.001$ ), decide on their own procedures for solving complex problems $(\mathrm{b}=9.49$, standardized difference $=0.13, \mathrm{p}<.01)$, and to work on problems for which there is no immediately obvious method of solution $(b=7.05$, standardized difference $=0.09$, $\mathrm{p}<.05)$ were each associated with increased mathematics scores, after controlling for the covariates included in the models. The largest predicted increase in achievement was associated with U.S. teachers having their students write equations and functions to represent relationships; recall that teachers in the U.S. were significantly less likely than teachers in Japan and Korea to have their students engage in this practice (Table 3). For every one point increase in teachers' practice of having their students write equations and functions to represent relationships (e.g., increasing the frequency of using this practice from some lessons to about half the lessons), students' mathematics scores were predicted to increase by 0.33 standard deviations.

Tables 5 and 6 show that in Korea and Japan, none of the six individual teaching for conceptual understanding items was significantly associated with students' mathematics test scores; the regression coefficients and standardized difference associated with the individual practice items were small; between -0.08 and 0.01 in Korea and between -0.003 and 0.11 in Japan.

Table 7 shows that in Singapore, the frequency with which teachers asked their students to write equations and functions to represent relationships $(\mathrm{b}=28.38$, standardized difference $=0.32, \mathrm{p}<.001$ ), apply facts, concepts and procedures to solve routine problems $(b=20.43$, standardized difference $=0.23, \mathrm{p}<.01)$, and to work on problems for which there is no immediately obvious method of solution $(b=33.68$, standardized difference $=0.37$, $\mathrm{p}<.001)$ were each associated with increased mathematics test scores, after controlling for the student and school covariates in the model.

Two patterns were apparent in these results. In Korea and Japan the items used to represent teaching for conceptual understanding were not associated with students' mathematics test scores. Conversely in the U.S. and Singapore, students in classrooms where teachers asked their students to write equations and functions to represent relationships or work on problems for which there is no immediately obvious method of solution were predicted to have higher mathematics scores, after controlling for all other variables in the model. The standardized regression coefficients for having students write equations and functions to represent relationships were almost identical in both countries; 0.33 in the U.S. compared to 0.32 in Singapore.

The percentage of variance explained by the predictors in the models corroborates these findings. Table 8 shows the percentage of variance in mathematics achievement within and between schools, and the variance explained (within and between schools, and in total) by the items representing teaching for conceptual understanding, and the student and school covariates. The variance in achievement within schools and between schools (the ICC) varied across the four countries; however, the U.S. is most similar to Singapore with respect to how the variance in mathematics scores is distributed. In both countries, more than half of the variability in students' scores lies among schools, $57.1 \%$ in the U.S. and $73.9 \%$ in Singapore, suggesting that students in the U.S. and Singapore are likely to attend schools with students who are similar to themselves. 
Table 8 Variance in mathematics achievement explained by the measures of teaching for conceptual understanding

\begin{tabular}{|c|c|c|c|c|c|c|c|c|c|c|}
\hline & & & & $\begin{array}{l}\text { Covariates- } \\
\text { Only } \\
\text { Model }^{\dagger}\end{array}$ & $\begin{array}{l}\text { Model } 1 \\
\text { Interpret data }\end{array}$ & $\begin{array}{l}\text { Model } 2 \\
\text { Write equations }\end{array}$ & $\begin{array}{l}\text { Model } 3 \\
\text { Apply facts }\end{array}$ & $\begin{array}{l}\text { Model } 4 \\
\text { Relate learning }\end{array}$ & $\begin{array}{l}\text { Model } 5 \\
\text { Decide on procedures }\end{array}$ & $\begin{array}{l}\text { Model } 6 \\
\text { Work on problems }\end{array}$ \\
\hline \multirow[t]{4}{*}{ U.S. } & Variance Available: & & \% Explained: & & & & & & & \\
\hline & ....within schools & $57.1 \%$ & ...within schools & $38.4 \%$ & $38.4 \%$ & $38.4 \%$ & $38.4 \%$ & $38.4 \%$ & $38.4 \%$ & $38.4 \%$ \\
\hline & ....btn schools (ICC) & $42.9 \%$ & ...btn schools & $52.9 \%$ & $52.8 \%$ & $57.1 \%$ & $52.8 \%$ & $52.6 \%$ & $54.2 \%$ & $53.2 \%$ \\
\hline & & & ....Total & $44.6 \%$ & $44.6 \%$ & $46.4 \%$ & $44.6 \%$ & $44.5 \%$ & $45.2 \%$ & $44.8 \%$ \\
\hline \multirow[t]{4}{*}{ Korea } & Variance Available: & & \% Explained: & & & & & & & \\
\hline & .....within schools & $89.4 \%$ & ...within schools & $40.1 \%$ & $40.1 \%$ & $40.1 \%$ & $40.1 \%$ & $40.1 \%$ & $40.1 \%$ & $40.1 \%$ \\
\hline & ....bth schools (ICC) & $10.6 \%$ & ...btn schools & $68.4 \%$ & $70.2 \%$ & $68.3 \%$ & $68.9 \%$ & $68.2 \%$ & $68.2 \%$ & $68.5 \%$ \\
\hline & & & ....Total & $43.1 \%$ & $43.3 \%$ & $43.1 \%$ & $43.1 \%$ & $43.1 \%$ & $43.1 \%$ & $43.1 \%$ \\
\hline \multirow[t]{4}{*}{ Japan } & Variance Available: & & \% Explained: & & & & & & & \\
\hline & ....within schools & $80.1 \%$ & ...within schools & $26.4 \%$ & $26.4 \%$ & $26.4 \%$ & $26.4 \%$ & $26.4 \%$ & $26.4 \%$ & $26.4 \%$ \\
\hline & ....bth schools (ICC) & $19.9 \%$ & ...btn schools & $35.1 \%$ & $34.8 \%$ & $34.4 \%$ & $34.6 \%$ & $34.7 \%$ & $37.8 \%$ & $39.5 \%$ \\
\hline & & & ....Total & $28.1 \%$ & $28.1 \%$ & $28.0 \%$ & $28.0 \%$ & $28.0 \%$ & $28.7 \%$ & $29.0 \%$ \\
\hline \multirow[t]{4}{*}{ Singapore } & Variance Available: & & \% Explained: & & & & & & & \\
\hline & ....within schools & $26.1 \%$ & ... within schools & $22.5 \%$ & $22.5 \%$ & $22.5 \%$ & $22.5 \%$ & $22.5 \%$ & $22.5 \%$ & $22.5 \%$ \\
\hline & ....bth schools (ICC) & $73.9 \%$ & ...btn schools & $75.4 \%$ & $75.3 \%$ & $75.4 \%$ & $75.4 \%$ & $75.3 \%$ & $76.0 \%$ & $76.1 \%$ \\
\hline & & & ....Total & $61.6 \%$ & $61.5 \%$ & $61.6 \%$ & $61.6 \%$ & $61.6 \%$ & $62.0 \%$ & $62.1 \%$ \\
\hline
\end{tabular}


In Korea and Japan, the majority of variance in mathematics scores is among students within schools, $89.4 \%$ in Korea and $80.1 \%$ in Japan. The small percentages of variance in achievement between schools suggests that teacher-to-teacher differences in teaching for conceptual understanding practices, or any teacher- or classroom-level practice or characteristic for that matter, will be of limited use in predicting student-to-student differences in achievement in these countries.

Recall that only one classroom per school is included in the analysis sample. As a consequence, the variance in achievement between classroom within schools and the between school variance in achievement are confounded, so the proportion of variability between schools is larger than is observed when classroom-to-classroom differences are separated from between school differences. For example, when multiple classrooms per school are included in the analysis in the U.S., a three-level model indicates that approximately $40 \%$ of the variability in mathematics performance lies between students within classrooms, $47 \%$ between classrooms within schools, and $12 \%$ between schools. In Singapore, the only other country with large numbers of schools with more than one classroom, approximately $23 \%$ of the variability in mathematics performance lies between students within classrooms, $53 \%$ between classrooms within schools, and $24 \%$ between schools.

Table 8 also presents the variance components for the covariates-only model (fixed effects not presented), and for each of Models 1 through 6 in the four countries. The student and school covariates explained similar percentages of the total variance in students' mathematics scores in the U.S. and Korea, $44.6 \%$ and $43.1 \%$, respectively. In Singapore however, the student and school covariates explained approximately $62 \%$ of the total variance in achievement $-22.5 \%$ of the $26.1 \%$ available within schools, and $75.4 \%$ of the $73.9 \%$ between schools.

Despite being significantly associated with achievement in the U.S. and Singapore (Tables 4 and 7), the frequency with which teachers asked their students to write equations and functions to represent relationships and work on problems for which there is no immediately obvious method of solution explained only very small percentages of the total variance in students' scores after controlling for the covariates in the model (between 0.2 and 1.6 additional percentage points). Likewise, having students decide on their own procedures for solving complex problems did not explain any additional variance in achievement in the U.S., and having students apply facts, concepts and procedures to solve routine problems did not explain any additional variance in achievement in Singapore.

The percentage of variance explained in Korea and Japan corroborate the findings in Tables 5 and 6 that these measures of teaching for conceptual understanding were not associated with mathematics test scores; Models 1 through 6 explained no additional variance over and above the percentage of variance explained by the covariates.

\section{Student and school covariates and mathematics test scores}

Though not central to the research questions posed, patterns were also evident in the regression coefficients associated with the student and school covariates across the four countries. The only significant effect for gender was observed in the U.S., with the difference favoring males. In the three East Asian countries, students' with more positive attitudes toward mathematics (higher on the PAT-M index), students who valued mathematics (higher on the SVM index), and had greater self-confidence in 
learning mathematics (higher on the SCM index) were predicted to have higher mathematics scores. However, in the U.S., only students' self-confidence in learning mathematics was associated with mathematics test scores. In all countries, the composite representing students' home background and the school aggregated home background composite were significantly associated with mathematics test scores; students from better resourced homes and students in schools where the student body come from well-resourced homes were predicted to have significantly higher mathematics scores.

\section{Conclusion and discussion}

Educators, researchers and policy-makers worldwide continue to struggle to understand the changes that need to be made to improve educational outcomes and educational attainment for students, particularly in content areas such as mathematics and science that are essential for developing a highly skilled workforce. It is evident from the vast body of educational research that the correlates of student achievement and attainment are many and varied, particularly across countries, and that it is unlikely we will be able to isolate a single policy or practice that will alone, resolve all the concerns around improving student outcomes.

In the U.S., state and federal initiatives such as the Race to the Top program have renewed the emphasis on linking teacher quality with student outcomes. In reality, teacher quality is a complex construct that almost certainly hinges on teachers' instructional practices, pedagogical content knowledge, attitudes toward students and teaching, as well as pre-service qualifications and professional development activities (Darling-Hammond and Youngs, 2002; Goe, 2007). However, while U.S. federal policies support the idea that how teachers teach is central to teacher quality, there appears to be little consensus on the specific instructional practices that are consistently associated with student achievement. The focus of this research was on developing a deeper understanding of the types of instructional practices, particularly practices supporting conceptual understanding, used by U.S. teachers compared to teachers in a subset of higher-performing East Asian countries, and to examine whether those instructional practices were related to students' mathematics test scores.

In conducting this study, the authors acknowledge that one of the most significant challenges for comparing the relationships between student test scores in U.S. to the test scores of students in East Asian countries is the pervasiveness of out-of-school instruction in those countries, particularly in mathematics (Bray, 2003; Bray and Kwo, 2013). The proliferation of for-profit, supplementary instruction through juku or hagwons is likely to affect the validity of the comparisons, and unfortunately the extent of the effect is difficult to estimate using data from large-scale, international studies such as TIMSS, PIRLS, and PISA.

The descriptive results presented here support the findings from previous studies, including classroom observation studies, that there is variability across countries in teachers' use of instructional practices for supporting conceptual understanding (Hiebert et al., 2005; VanTassel-Baska et al., 2008; Whitman and Lai, 1990). Focusing on how the U.S. compares to the other countries, it appeared that teachers in the U.S. were most similar to Korean teachers in the frequency of their reported practices, and that they reported using some of the practices at least as frequently, or more frequently than 
teachers in the other countries. This pattern is somewhat at odds with previous research findings about teaching practices in the U.S. For example, Hiebert et al. (2005) concluded from the 1999 TIMSS video study that, compared to higher performing countries, teachers in the U.S. spent more time completing repetitive exercises rather than applying and extending skills to new, different problems. In contrast, these data show that teachers in U.S. classrooms reported rates for having their students apply facts, concepts and procedures to solve routine problems, relate what they are learning in mathematics to their daily lives, decide on their own procedures for solving complex problems, and work on problems for which there is no immediately obvious method of solution that were as high, or higher than the top-performing comparison countries.

One possible explanation for the patterns observed may be differences in how the survey items are interpreted across countries, a significant challenge in any international study that uses self-report surveys. For example, when presented with a survey item that uses the term "complex problem" there may be cultural differences in what constitutes "complex"; something that is considered complex in one culture may be characterized as basic in another. Likewise, it is also possible that the different patterns observed in this study are due to the data being gathered from self-reports only, with no classroom observations or interviews to verify the results. Unfortunately, in the absence of observational or interview data, it is difficult to disconfirm the hypothesis that crosscultural interpretation differences underlie the response patterns.

In Japan, the pattern of responses about use of practices that support conceptual understanding was at odds with the findings from previous TIMSS administrations. For example in TIMSS 1999, Japan led the other nations in teaching for conceptual understanding in eighth grade mathematics classrooms, ranking first in the frequency of using such practices (Mullis et al., 2000). Moreover, the TIMSS video study, also conducted in 1999, came to the same conclusion based on classroom observations (Hiebert et al., 2005). However, the patterns observed here for TIMSS 2007 suggest there may have been changes in Japanese teachers' practices in the intervening years; teachers in Japan no longer reported using the six strategies as frequently as in previous TIMSS administrations. Overall, teachers in Korea, and in some cases the U.S., employed these strategies more frequently than teachers in Japan.

In looking at whether teachers' instructional practices for supporting conceptual understanding were related to students' mathematics achievement, two interesting patterns were observed. The relationships observed between teachers' instructional practices and mathematics achievement in the U.S. and Singapore were similar. Of the six teaching for conceptual understanding practices examined, two were significantly associated with achievement in both countries. These were: the frequency with which teachers had their students write equations and functions to represent relationships and work on problems for which there is no immediately obvious method of solution, one of the most complex conceptual skills at the higher end of the construct of teaching for conceptual understanding (Hiebert and Grouws, 2007). In terms of a standardized effect size, the largest predicted change in mathematics achievement was associated with teachers having their students write equations and functions to represent relationships. Holding all else constant, increasing the frequency of using this practice from say some lessons to about half the lessons was associated with a predicted increase in achievement of 0.33 standard deviations in the U.S. and 0.33 standard deviations in Singapore. In each 
of these two countries, one additional instructional practice was associated with higher mathematics test scores: having students decide on their own procedures for solving complex problems in the U.S., and in Singapore, having students apply facts, concepts and procedures to solve routine problems, one of the less complex skills at the lower end of the construct (Hiebert and Lefevre, 1987).

Although teachers in the U.S. had their students write equations and functions to represent relationships less frequently than teachers in Korea and Japan, the significant regression coefficient in the U.S. indicates that, even after controlling for student and school covariates, this instructional strategy may be effective when used. This result in the U.S. aligns with Camburn and Han's meta-analysis (Camburn and Han, 2011) that reported statistically significant support for the positive association between achievement and certain instructional practices. However, it is at odds with Tomoff et al.'s (2000) study of the earlier TIMSS 1995 data, which based on the analysis of slightly different survey items relating to teaching practices, did not find even a weak relationship between achievement and instructional practices in the U.S.

Likewise, although teachers in Singapore reported some of the lowest frequencies of having their students write equations and functions to represent relationships, apply facts, concepts and procedures to solve routine problems, and work on problems for which there is no immediately obvious method of solution among the four countries studied, these practices were each positively associated with mathematics achievement.

However, despite observing a statistically significant relationship between some of the instructional practice measures and mathematics achievement in the U.S. and Singapore, the measures explained very small percentages of the variability in mathematics achievement (between 0.2 and 1.6 additional percentage points). These percentages were similar to those reported by Desimone, Smith, Baker and Ueno's TIMSS 1999 study (Desimone et al. 2005) who found that the relationship between mathematics achievement and the frequency of using strategies for teaching for conceptual understanding were weak in the U.S. The results from this study confirm that differences in instructional practices may not be the largest contributing factor to the observed differences in achievement between U.S. students and students in higher-scoring, East Asian countries.

First, teachers' uses of instructional practices were not associated with students' total mathematics scores in Korea or Japan. Though not presented as part of this research, this finding held when we looked at students' sub-domain scores in Numbers, Algebra, Geometry, and Data and Chance, and when we included or excluded the student and school covariates from the model. This finding may be due to the small proportion of variability in achievement among schools in Korea and Japan that is available to be explained by differences in teachers' instructional practices. Compared to the U.S. and Singapore where $57.1 \%$ and $73.9 \%$ of the variability in mathematics achievement existed between schools, respectively, only $10.6 \%$ of the variability in mathematics achievement exists between schools in Korea, and $19.9 \%$ in Japan. Furthermore, in Korea, more than two-thirds of the small proportion of available variance in mathematics scores between schools was accounted for by the covariates, leaving even less to be explained by differences in teachers' uses of instructional practices.

As with any study of this nature, there are additional considerations in the interpretation of the findings presented here, some of which are intractable issues when conducting 
secondary analyses with large-scale, international comparative study data. First, the most obvious limitation of this research is that it cannot support causal claims about the observed relationships between teachers' instructional practices and student test scores. Being a cross-sectional observational study that does not include information about students' prior achievement, these data do not support claims about whether student achievement is influenced by teachers' instructional practices, or whether teachers are using particular practices because they have high achieving students. Related to this point is the self-reported nature of the information provided by the teachers; stronger evidence for the existence of the relationship, or lack of relationship, between instructional practices and student outcomes would require studies to include a classroom observation component.

Second, the data analyzed to address the research questions were derived from the survey data collected as part of the TIMSS 2007 study. So, although the TIMSS documentation reports that the practices measured on the surveys were those deemed by TIMSS developers and its partners to be most effective for mathematics instruction (Mullis et al., 2005), they may not be culturally attuned to the practices that teachers use in some East Asian countries. In this sense, we cannot be certain that other, perhaps similar instructional practices are not associated with student test scores. In addition, there is the possibility that teachers from different cultures interpreted the survey items in different ways. Also, since teachers were not asked to indicate the amount of time spent per lesson on the different teaching practices, it was not possible to discern whether time spent using particular teaching strategies was associated with the observed differences between countries.

Third, the analysis sample was selected according to strict exclusion criteria and resulted in the removal of many students and schools. The comparison presented in Table 1 indicates that the reported samples (Mullis et al., 2008) and analysis samples were similar in terms of mean achievement, variability in achievement, and in the percentages of students whose teachers asked them to engage in the six activities in about half the lessons or more. However, it is possible that the reported and analysis samples differ on other characteristics and that bias may have been introduced with the removal of students and schools.

Finally, one possible explanation for the observed differences in mathematics achievement between countries may be the pervasiveness of supplementary, out-of-school instruction for East Asian students (Bray, 2003; Bray and Kwo, 2013). While in 1995, 1999, and 2003 TIMSS asked students how much time they spent outside of school receiving instruction in mathematics, this question was omitted from TIMSS 2007, precluding researchers and policy makers from exploring this hypothesis. Given the increase in out-of-school instruction in some countries, we would recommend that a question relating to out-of-school instruction be re-introduced in future TIMSS studies.

To conclude, while acknowledging these limitations, the authors believe that the evidence presented in this research contributes to our understanding of the complexity of teachers' pedagogical practices in the classroom and points to the need for more nuanced research in this area. In particular, additional efforts should be undertaken in international comparative studies to estimate the effects of out-of-school instruction on students' test scores, and to disentangle those effects from the effects of countries' formal education systems. 


\section{Endnote}

${ }^{\mathrm{a}}$ As the research conducted here is a secondary data analysis no human subjects were involved and the research is exempt under our organizations' Institutional Review Boards.

Competing interests

The authors declare that they have no competing interests.

\section{Authors' contributions}

LOD, YW and KS participated in the development of the rationale for the study. YW prepared the data for analysis. LOD and YW conducted the analyses. LOD drafted the manuscript with contributions from YW and KS. All authors read and approved the final manuscript.

\section{Author details}

'Department of Educational Research, Measurement and Evaluation, Lynch School of Education, Boston College, Chestnut Hill, Massachusetts, USA. Wisconsin Center for Education Research, University of Wisconsin-Madison, Madison, Wisconsin, USA. ${ }^{3}$ Department of Educational Research, Measurement and Evaluation, Lynch School of Education, Boston College, Chestnut Hill, Massachusetts, USA.

Received: 31 January 2014 Accepted: 4 December 2014

Published online: 05 February 2015

\section{References}

Berliner, DC. (2006). Our impoverished view of educational research. Teachers College Record, 108(6), 949-995.

Borman, GD, \& Kimball, SM. (2005). Teacher quality and educational quality: Do teachers with higher standards-based evaluation ratings close student achievement gaps? The Elementary School Journal, 106(1), 3-20.

Bray, M. (2003). Adverse Effects of Supplementary Private Tutoring: Dimensions, Implications, and Government Responses (UNESCO International Institute for Educational Planning, p. 84). Downloaded November, 2013.

Bray, M, \& Kwo, O. (2013). Behind the façade of fee-free education: Shadow education and its implications for social justice. Oxford Review of Education, 39(4), 480-497.

Camburn, EM, \& Han, SW. (2011). Two decades of generalizable evidence on U.S. instruction from national surveys. Teachers College Record, 113(3), 561-610.

Choi, N, \& Chang, M. (2011). Interplay among school climate, gender, attitude toward mathematics, and mathematics performance of middle school students. Middle Grades Research Journal, 6(1), 15-28.

D'Agostino, J. (2000). Instructional and school effects on students' longitudinal reading and mathematics achievements. School Effectiveness and School Improvement, 11(2), 197-235.

Darling-Hammond, L, \& Youngs, P. (2002). Defining "highly qualified teachers": What does "scientifically-based research" actually tell us? Educational Researcher, 31(9), 13-25.

Desimone, LM, Smith, T, Baker, D, \& Ueno, K. (2005). Assessing barriers to the reform of U.S. mathematics instruction from an international perspective. American Educational Research Journal, 42(3), 501-535.

DeVellis, RF. (2012). Scale Development: Theory and Applications (3rd ed.). Washington, D.C.: SAGE Publications.

diSessa, AA, \& Sherin, BL. (1998). What changes in conceptual change? International Journal of Science Education, 20(10), 1155-1191.

Else-Quest, NM, Hyde, JS, \& Linn, MC. (2010). Cross-national patterns of gender differences in mathematics: A meta-analysis. Psychological Bulletin, 136(1), 103-127.

Fennema, E, Carpenter, TP, Franke, ML, Levi, L, Jacobs, VR, \& Empson, SB. (1996). A longitudinal study of learning to use children's thinking in mathematics instruction. Journal for Research in Mathematics Education, 27(4), 403-434.

Foy, P, Galia, J, \& Li, I. (2008). Scaling the data from the TIMSS 2007 mathematics and science assessments. Chapter 11. In JF Olson, MO Martin, \& IVS Mullis (Eds.), TIMSS 2007 technical report (pp. 225-280). Chestnut Hill, MA: TIMSS \& PIRLS International Study Center, Boston College.

Gales, MJ, \& Yan, W. (2001). Relationship between constructivist teacher beliefs and instructional practices to students' mathematical achievement: Evidence from TIMSS (Paper presented at the annual meeting of the American Educational Research Association, Seattle, WA).

Gallagher, HA. (2004). Vaughn Elementary's innovative teacher evaluation system: Are teacher evaluation scores related to growth in student achievement? Peabody Journal of Education, 79(4), 79-107.

Gearhart, M, Saxe, GB, Seltzer, M, Schlackman, J, Ching, CC, Nasir, N, \& Sloan, TF. (1999). Opportunities to learn fractions in elementary mathematics classrooms. Journal for Research in Mathematics Education, 30(3), 286-315.

Goe, L. (2007). The link between teacher quality and student outcomes: A research synthesis. Washington, DC: National Comprehensive Center for Teacher Quality.

Hattie, JAC. (2009). Visible learning: A synthesis of over 800 meta-analyses relating to achievement. New York: Routledge.

Heck, RH. (2007). Examining the relationship between teacher quality as an organizational property of schools and students' achievement and growth rates. Educational Administration Quarterly, 43(4), 399-432.

Henderson, AT, \& Berla, N. (1994). A new generation of evidence: The family is critical to student achievement. St. Louis, MO: Danforth Foundation and Flint, MI: Mott (C. S.) Foundation.

Heneman, HG, Milanowski, A, Kimball, SM, \& Odden, A. (2006). Standards-based teacher evaluation as a foundation for knowledge- and skill-based pay (CPRE Policy Brief No. RB-45). Philadelphia: Consortium for Policy Research in Education.

Hiebert, J. (2003). What research says about the NCTM Standards. In J Kilpatrick, WG Martin, \& D Schifter (Eds.), A research companion to Principles and Standards for School Mathematics (pp. 5-23). Reston, VA: The National Council of Teachers of Mathematics, Inc. 
Hiebert, J, \& Grouws, DA. (2007). The effects of classroom mathematics teaching on students' learning. In FK Lester (Ed.), Second handbook for research in mathematics teaching and learning: A project of the National Council of Teachers of Mathematics (pp. 371-404). Charlotte, NC: Information Age Publishing.

Hiebert, J, \& Lefevre, P. (1987). Conceptual and procedural knowledge in mathematics: An introductory analysis. In J Hiebert (Ed.), Conceptual and procedural knowledge: The case of mathematics (pp. 1-28). Hillsdale, NJ: Lawrence Erlbaum Associates, Inc.

Hiebert, J, Stigler, JW, Jacobs, JK, Givvin, KB, Garnier, H, Smith, M, \& Gallimore, R. (2005). Mathematics teaching in the United States today (and tomorrow): Results from the TIMSS 1999 video study. Educational Evaluation and Policy Analysis, 27(2), 111-132.

Hill, HC, Rowan, B, \& Ball, DL. (2005). Effects of teachers' mathematical knowledge for teaching on student achievement. American Educational Research Journal., 42, 371-406.

Ho, H, Senturk, D, Lam, AG, Zimmer, JM, Hong, S, Okamoto, Y, \& Wang, C. (2000). The affective and cognitive dimensions of mathematics anxiety: A cross-national study. Journal for Research in Mathematics Education, 31(3), $362-379$.

Holtzapple, E. (2003). Criterion-related validity evidence for a standards-based teacher evaluation system. Journal of Personnel Evaluation in Education, 17(3), 207-219.

House, JD. (2009). Elementary-school mathematics instruction and achievement of fourth-grade students in Japan: Findings from the TIMSS 2007 Assessment. Education, 130(2), 301-307.

Jacobs, JK, \& Morita, E. (2002). Japanese and American teachers' evaluations of videotaped mathematics lessons. Journal for Research in Mathematics Education, 33, 154-175.

Joncas, M. (2008). TIMSS 2007 Sample Design. In JF Olson, MO Martin, \& IVS Mullis (Eds.), TIMSS 2007 technical report (pp. 77-92). Chestnut Hill, MA: TIMSS \& PIRLS International Study Center, Boston College.

Kaiser, G, \& Blömeke, S. (2013). Learning from the Eastern and the Western debate: The case of mathematics teacher education. ZDM Mathematics Education, 45, 7-19.

Kim, RY, Ham, S, \& Paine, LW. (2011). Knowledge expectations in mathematics teacher preparation programs in South Korea and the United States: Towards international dialogue. Journal of Teacher Education, 62(1), 48-61.

Kimball, SM, White, B, Milanowski, AT, \& Borman, G. (2004). Examining the relationship between teacher evaluation and student assessment results in Washoe County. Peabody Journal of Education, 79(4), 54-78.

Lewis, KA, \& Seidman, LS. (1994). Mathematics-time capital matters: A cross-country analysis. Economics of Education, 13(3), 215-226.

Little, RJA, \& Rubin, DB. (2002). Statistical analysis with missing data (2nd ed.). New York: Wiley.

Liu, OL, \& Wilson, M. (2009). Gender differences in large-scale mathematics assessments: PISA Trend 2000 and 2003. Applied Measurement in Education, 22(2), 164-184.

Lubienski, ST. (2006). Examining instruction, achievement, and equity with NAEP mathematics data. Education Policy Analysis Archives, 14(14). Retrieved Sep. 23, 2010 from http://epaa.asu.edu/ojs/article/view/85.

$\mathrm{Ma}, \mathrm{X}$, \& Kishor, N. (1997). Assessing the relationship between attitude toward mathematics and achievement in mathematics: A meta-analysis. Journal for Research in Mathematics Education, 28(1), 26-47.

Martin, MO, \& Preuschoff, C. (2008). Creating the TIMSS 2007 Background Indices. In JF Olson, MO Martin, \& IVS Mullis (Eds.), TIMSS 2007 technical report (pp. 281-338). Chestnut Hill, MA: TIMSS \& PIRLS International Study Center, Boston College.

McCoach, DB. (2010). Hierarchical linear modeling. In GR Hancock \& RO Mueller (Eds.), Quantitative methods in the social and behavioral sciences: A guide for researchers and reviewers (pp. 123-140). New York: Routledge.

Mewborn, DS. (2003). Teaching, teachers' knowledge, and their professional development. In J Kilpatrick, WG Martin, \& D Schifter (Eds.), A research companion to Principles and Standards for School Mathematics (pp. 45-52). Reston, VA: The National Council of Teachers of Mathematics, Inc.

Milanowski, A. (2004). The relationship between teacher performance evaluation scores and student achievement: Evidence from Cincinnati. Peabody Journal of Education, 79(4), 33-53.

Mullis, IVS, Martin, MO, Gonzalez, EJ, Gregory, KD, Garden, RA, O'Connor, KM, \& Smith, TA. (2000). TIMSS 1999 international mathematics report: Findings from IEA's repeat of the Third International Mathematics and Science Study at the eighth grade. Chestnut Hill, MA: The International Study Center, Boston College.

Mullis, IVS, Martin, MO, Ruddock, GJ, O'Sullivan, CY, Arora, A, \& Erberber, E. (2005). TIMSS 2007 assessment frameworks. Chestnut Hill, MA: TIMSS\& PIRLS International Study Center, Lynch School of Education, Boston College.

Mullis, IVS, Martin, MO, Foy, P, Olson, JF, Preuschoff, C, Erberber, E, Arora, A, \& Galia, J. (2008). TIMSS 2007 international mathematics report: Findings from IEA's trends in international mathematics and science study at the fourth and eighth grades. Chestnut Hill, MA: TIMSS \& PIRLS International Study Center, Boston College.

National Council of Teachers of Mathematics. (2000). Principles and standards for school mathematics. Reston, VA: NCTM.

Newmann, FM, Bryk, AS, \& Nagaoka, JK. (2001). Authentic intellectual work and standardized tests: Conflict or coexistence? Chicago: Consortium on Chicago School Research.

OECD. (2010). PISA 2009 at a glance. Paris, France: OECD Publishing.

Prawat, RS. (1989a). Teaching for understanding: Three key attributes. Teaching and Teacher Education, 5, 315-328.

Prawat, RS. (1989b). Promoting access to knowledge, strategy, and disposition in students: A research synthesis. Review of Educational Research, 59, 1-41.

Raudenbush, SW, \& Bryk, AS. (2002). Hierarchical linear models: Applications and data analysis methods (2nd ed.). Thousand Oaks, CA: Sage.

Robinson, JP, \& Lubienski, ST. (2011). The development of gender achievement gaps in mathematics and reading during elementary and middle school: Examining direct cognitive assessments and teacher ratings. American Educational Research Journal, 48(2), 268-302.

Rothstein, R. (2004). Class and schools: Using social, economic, and educational reform to close the Black-White achievement gap. Washington, D.C.: Economic Policy Institute.

Rowan, B, Chiang, FS, \& Miller, RJ. (1997). Using research on employees' performance to study the effects of teachers on students' achievement. Sociology of Education, 70, 256-284. 
Rumberger, RW, \& Palardy, GJ. (2005). Does segregation still matter? The impact of student composition on academic achievement in high school. Teachers College Record, 107(9), 1999-2045.

Schacter, J, \& Thum, YM. (2004). Paying for high- and low-quality teaching. Economics of Education Review, 23, 411-430. Schmidt, WH, \& Cogan, LS. (1996). Development of the TIMSS context questionnaires. In MO Martin \& DL Kelly (Eds.), Third international mathematics and science study technical report, volume l: design and development. Boston College: Chestnut Hill, MA.

Schmidt, WH, Wang, HC, \& McKnight, CC. (2005). Curriculum coherence: An examination of U.S. mathematics and science content standards from an international perspective. Journal of Curriculum Studies, 37(5), 525-559.

Schreiber, JB. (2002). Institutional and student factors and their influence on advanced mathematics achievement. Journal of Educational Research, 95(5), 274-286.

Singh, K, Granville, M, \& Dika, S. (2002). Mathematics and science achievement: Effects of motivation, interest, and academic engagement. Journal of Educational Research, 95(6), 323-332.

Sirin, S. (2005). Socioeconomic status and academic achievement: A meta-analytic review of research. Review of Educational Research, 75(3), 417-453.

Star, JR. (2005). Reconceptualizing procedural knowledge. Journal for Research in Mathematics Education, 36, 404-411.

Tomoff, J, Thompson, M, \& Behrens, J. (2000). Measuring NCTM-recommended practices and student achievement with TIMSS (Paper presented at the annual meeting of the American Educational Research Association, New Orleans, LA).

VanTassel-Baska, J, Feng, A, MacFarlane, B, Heng, M, Teo, CT, Wong, ML, \& Khong, BC. (2008). A cross-cultural study of teachers' instructional practices in Singapore and the United States. Journal for the Education of the Gifted, 31(3), 338-363.

Votruba-Drzal, E. (2006). Economic disparities in middle childhood development: Does income matter? Developmental Psychology, 42(6), 1154-1167.

Wenglinsky, H. (2002). How schools matter: The link between teacher classroom practices and student academic performance. Education Policy Analysis Archives, 10(12), 1-30.

Whitman, NC, \& Lai, MK. (1990). Similarities and differences in teachers' beliefs about effective teaching of mathematics: Japan and Hawai'i. Educational Studies in Mathematics, 21, 71-81.

Yeung, WJ, Linver, MR, \& Brooks-Gunn, J. (2002). How money matters for young children's development: Parental investment and family processes. Child Development, 73(6), 1861-1879.

\section{Submit your manuscript to a SpringerOpen ${ }^{\circ}$} journal and benefit from:

- Convenient online submission

- Rigorous peer review

- Immediate publication on acceptance

- Open access: articles freely available online

- High visibility within the field

- Retaining the copyright to your article

Submit your next manuscript at $>$ springeropen.com 